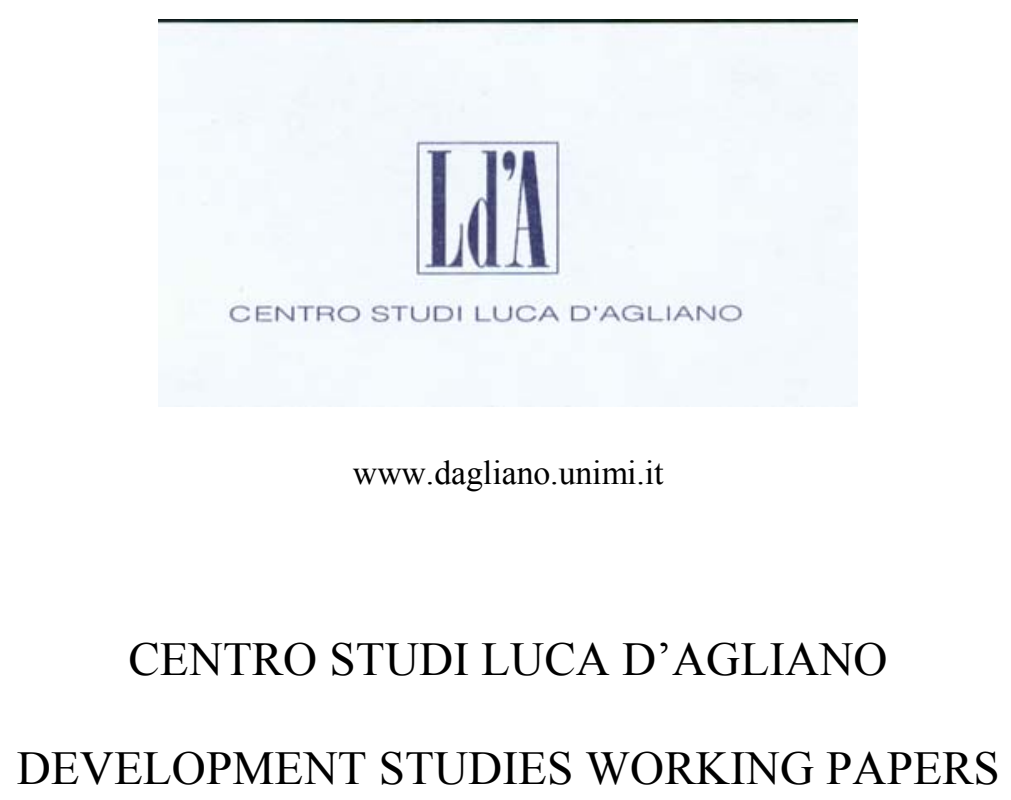

N. 189

October 2004

What does motivate lending and aid to the HIPCs?

\author{
Silvia Marchesi* \\ Alessandro Missale*
}

*University of Siena and University of Milano 


\title{
What does motivate lending and aid to the HIPCs?
}

\author{
Silvia Marchesi e Alessandro Missale* \\ University of Siena and University of Milano
}

10 August 2004

\begin{abstract}
We examine both grants and net loans made to low income countries during the last two decades to understand the main reasons that motivated the behaviour of both donors and creditors. We find that the total amount of net transfers to HIPCs, as compared to non-HIPCs, have been increasing with their debt level. Greater net transfers have taken the form of net loans from multilateral organisations and grants in exchange for loans from bilateral institutions. This evidence thus suggests that HIPCs have kept receiving large amounts of resources just because of their high indebtedness, thereby supporting both the hypothesis of defensive lending and defensive granting.
\end{abstract}

Keywords: debt relief, foreign aid, highly indebted poor countries.

JEL Classification: C23, F34, F35, O19.

\footnotetext{
${ }^{*}$ Corresponding author: Silvia Marchesi, Dipartimento di Economia Politica, Piazza S.Francesco 7, I-53100 Siena. Tel. +39 0577 235088; Fax. +39 0577 232661; E-mail: marchesi@unisi.it. We thank Emanuele Bacchiocchi, Daniele Checchi, Geske Dijkstra, Carlo Favero, Peter Kenen, Emanuela Marrocu, Luca Nunziata, Laura Sabani and seminar participants at the Universities of Bari, Milano, Pavia, Roma, 2003 Warwick Summer Workshop and 2004 Debt Relief Conference. Financial support from the Associazione Guido Carli is gratefully acknowledged.
} 


\section{Introduction}

Since the onset of the debt crises in 1982, while the debt situation of middle-income countries has improved significantly and many of them have been able to re-enter the international capital market, low income countries have continued to experience difficulties meeting their external debt-service obligations. Since 1988, Paris Club creditors recognised that most low-income countries required an actual reduction of their level of debt, more than repeated reschedulings on "standard terms." Thus, conditional on the adoption of an IMF adjustment programme, most of low-income countries reschedulings were made at concessional terms (they contained a grant element either in the principal or in the interest component). At the same time, concessional new loans were made by both bilateral and multilateral sources. (Low-income countries are listed in Table 1)

In September 1996, in order to deal with the specific problems of the most indebted and poorest countries (Heavily Indebted Poor Countries or HIPCs), the World Bank and the IMF have jointly proposed and implemented the so-called HIPCs Debt Initiative which aims at reducing the debt burdens of all eligible HIPCs to sustainable levels, provided that they adopt and pursue strong programmes of adjustment and reform. More recently, in 1999, the HIPCs Initiative has been enhanced with the aim of providing deeper and more rapid debt relief to a larger number of countries. (HIPCs are listed in Table 3).

In this paper we examine both grants and net loans, that is new loans net of total debt service (i.e. principal and interest payments) made to low income countries over the last two decades, to understand the main reasons that motivated the behaviour of both donors and creditors. We focus on HIPCs since they received the most generous treatment so far (see Easterly, 2002). In particular, we want to examine whether this continued transfers of resources has been motivated by humanitarian reasons or by the hope of stimulating development, say, by conditioning new loans and grants to the quality of policy and institutions, or by defensive lending aimed at avoiding default. The latter hypothesis has been recently advanced by Devarajan et al. (1999) and by Birdsall et al. (2002). ${ }^{1}$ In fact, the decision of both bilateral and especially multilateral organisations (chiefly the IMF, the World Bank and the Regional Development Banks) to extend loans and provide new resources to HIPCs cannot be explained by liquidity arguments, as the sustainability of their external debts was already recognized to be the problem in 1988 .

Few papers deals with the determinants of net official (and generally concessional) loans to low income developing countries despite a vast literature on foreign aid. Birdsall et al. (2002) investigate the factors that explain multilateral and bilateral net transfers, defined as the sum of grants and loans net of interest and principal repayments. Analysing a panel of 37 Sub-Saharan countries over the period 1978 to 1998, the authors find that net transfers were higher in poorer and smaller countries. However, the quality of their economic policy mattered little in explaining net transfers, as donors, especially bilaterals, made greater transfers to countries with high multilateral debt, despite their bad policies.

\footnotetext{
${ }^{1}$ As stressed by Devarajan et.al (1999), 30\% of aid in the period 1975-99 has been used to service the external debt.
} 
We examine the determinants of grants and net loans separately unlike Birdsall et al. (2002) who focus on aggregate net transfers (i.e. the sum of both net loans and grants). Indeed, despite multilateral and bilateral net loans to HIPCs are, in most cases, concessional and, as such, a part of aid, official net loans are substantially different from grants, if anything because loans unlike grants must be repaid. This distinction and the use of a dynamic panel allow us to reach different conclusions regarding the behaviour of bilateral and multilateral institutions. Finally, our larger sample of low-income countries, made of both HIPCs and non-HIPCs, allows us to introduce a control group in the empirical analysis and thus to test whether the positive relation of net loans and grants with the debt ratio found by Birdsall et al. arises because of "defensive lending" or because of humanitarian reasons.

We innovate on the empirical literature on foreign aid in three respects. First, by introducing "debt variables" among the donors' interest type of variables, we are able to assess their influence in the aid (and net loans) allocation choices (i.e. both the hypothesis of "defensive lending" and that of "defensive granting"). Secondly, we separate between net loans and grants, bearing in mind that they are alternative ways to allocate scarce resources to low income countries. Finally, we distinguish loans by type of creditor in order to examine whether the behaviour of donors and creditors is affected by the decisions of the other creditors and donors, an important aspect that has so far been neglected.

We empirically investigate whether a high debt and its composition by type of creditor played an important role in explaining the allocation of grants and net loans to HIPCs while controlling for their characteristics and economic performance. Specifically, our hypothesis is that net loans and grants have continued to flow from rich countries to poor ones with the main objective of making poor countries able to keep servicing their debt while the quality of their policy framework has mattered little.

We find that a higher level of bilateral debt reduces bilateral net loans to HIPCs, while multilateral creditors appear strikingly more generous with HIPCs than with nonHIPCs. In particular, while a higher stock of debt owed to multilateral creditors tends to reduce the amount of their loans to non-HIPCs, this effect disappears in the case of HIPCs. The amount of loans, that the HIPCs receive, increases, compared to non-HIPCs, with the level of multilateral debt. This evidence points to defensive lending as the main motivation for the behaviour of multilateral organizations.

The aid policy of both bilateral and multilateral donors also appears more generous with HIPC than with non-HIPC countries, in that the amount of grants that each donor type provides to HIPCs significantly increases, compared to non-HIPCs, with its corresponding debt share. This suggests that a concern for debt sustainability might motivate the aid policy of both bilateral and multilateral donors, thereby supporting the hypothesis of "defensive granting".

Finally, as the aid additionality issue is concerned, we find a significant coefficient of debt forgiveness in the bilateral grants equation, independently of the type of country considered, which is a cause of concern as it is likely to reduce the amount of resources 
available to all low-income countries. ${ }^{2}$

This paper is organised as follows. In Section 2 we present some descriptive evidence on net loans and grants while Section 3 develops the empirical framework. Section 4 presents the results and Section 5 finally concludes.

\section{Loans and grants: descriptive evidence}

Over the last three decades, the debt-to-GDP ratio of Highly Indebted Poor Countries has steadily increased until the implementation of the HIPCs Initiative. The evolution of the HIPCs debt ratio is shown in Figure 1 (which compares it with the debt ratio evolution of all developing and of all low-income countries). This increase in debt ratios is well known and overly stressed in editorials calling for a solution of the debt-poverty trap afflicting African countries.

However, an economist not familiar with external debt problems may be puzzled by the rise in debt ratios between 1988 and 1994, as this occurred at a time when bilateral official creditors pledged to reduce the burden of poor debtor countries under the "Toronto terms" (1988), "London terms" (1991) and "Naples terms" (1994). If traditional debt relief agreements did reduce the net present value of debtors obligations, the effective relief was, however, modest and certainly below expectations. ${ }^{3}$ More importantly, debt relief was more than compensated by a greater amount of new borrowing. Actual figures show that in the period 1989 to 1999 total debt forgiveness was about $\$ 35$ billions while in the same period new borrowing reached $\$ 53$ billions.

Figure 1: Total External Debt \% GDP. 1970-99.

Even more puzzling is the claim that debt service (interest payments and redemption of maturing debt) is draining resources out of the debtor countries precluding development opportunities and throwing thousands of people into deep poverty. How could repayments be so large and debt growing so fast?

The relevant issue is whether resources have been moved away from the indebted countries to their international creditors (negative transfers) or resources have continued to flow into and benefit these countries (positive transfers). To estimate the net transfers that debtor countries have received over the years we must examine the evolution of new loans (disbursements) and then subtract the flows of debt service payments (interest and principal repayments). In fact, simply looking at the debt-to-GDP ratio could be misleading as debt may rise for several different reasons. A debt increase could reflect: (i) the transformation of interests payments into debt (that is, interests capitalized and interest arrears); (ii) the effect of cross-currency valuations and; (iii) the debt ratio could

\footnotetext{
${ }^{2}$ The hypothesis of "aid additionality" has been raised in recent studies of the HIPCs initiative and basically consists in a trade off between debt reduction and new aid (see Cohen, 2001).

${ }^{3}$ The net present value (NPV) of debt is defined as the sum of all future debt-service obligations (interest and principal) on existing debt, discounted at the market interest rate.
} 
also increase because of a fall in GDP that, when measured in dollars, is not a rare event for the countries under consideration.

In what follows, we focus on the evolution of net loans, that is, on the difference between new loans (i.e. disbursements) and total debt service (i.e. principal and interest repayments). We call this difference net loans instead of net transfers (which is the definition in the Global Development Finance) to emphasize that net loans do not include grants, which are the other important source of funds to the HIPCs. The period of time we consider goes from 1970 to 1999. Figure 2 shows that total debt service has been steadily increasing throughout this period but net loans have been positive, though declining, until 1997. Therefore, until 1997 (with the exceptions of 1994) new loans have been high enough to make indebted countries able to service their debt. It is only since 1998, that aggregate net loans turn out to be negative, thus providing support to the claim that the service of the outstanding debt is draining resources out of poor countries precluding development opportunities.

Figure 2: Total Debt Service and Total Net Loans \% GDP. HIPCs. 1970-99

A full picture of net resource flows from the international lending community to the HIPCs also requires examining grants, which represent the most important component of foreign aid and a clear alternative to net loans as a source of funding for the HIPCs. ${ }^{4}$ Figure 3 presents the evolution of grants (with and without technical cooperation) along with the evolution of both total and long-term net loans. ${ }^{5}$ Over the last two decades, grants have clearly been the most important funds to the HIPCs. While grants roughly followed the same pattern of net loans until the early eighties, they kept rising until the mid nineties. This steady increase thus compensated the fall in net loans over the period between 1984 and 1997, making stable the "total resources inflow".

Figure 3: Total Net Loans and Grants \% GDP. HIPCs. 1970-99

Finally, both grants and net loans decreased quite markedly after 1997. As shown in Figure 4, when grants (without technical cooperation) are added to net loans, their sum is always positive (while total net loans have been negative in 1994 and in 1998-99) and comprised in a range between 4 and 8 percent of GDP. In particular, Figure 4 shows that the amount of resources transferred to the HIPCs had been relatively stable in terms of GDP until the second half of the nineties, when net transfers fell substantially.

Figure 4: Total Net Loans \& w/o TC Grants and Total Net Loans \% GDP. HIPCs. 1970-99

Hence, in the nineties, while net loans fell substantially, and became negative since

\footnotetext{
${ }^{4}$ Foreign aid is usually associated with Official Development Assistance (ODA), which includes both official grants and official concessional loans (that is loans with at least a $25 \%$ percent grant component). ODA statistics are produced by the Development Assistance Committee (DAC) of the OECD. In turn, ODA can be divided into a bilateral and a multilateral component, which accounts for about $2 / 3$ and $1 / 3$ of all the resources, respectively (see Renard and Cassimon, 2001).

${ }^{5}$ Technical assistance relates to short and long-term experts from the donor countries working in developing countries, scholarship programmes and some other forms of human capital contributions.
} 
1998, the total resources transferred to the HIPCs (i.e. the sum of net loans and grants) remained positive. This fact raises the issue of whether grants can substitute normal money transfers. This mainly depends on the fungibility of (non technical) grants. The quality of grants, from the point of view of the recipients, is certainly lower than their monetary value, but a number of studies show that, though not completely, grants are a highly fungible source of financing (Devarajan et al., 1999). The reason is that grants tend to finance projects of high priority and thus they free resources from the budget for other uses.

To provide further insight, net loans can be distinguished by type of creditor. To this end, we focus on the distribution of long-term net loans, since the Global Development Finance provides disaggregated data only for this type of loans. Long-term net loans to the HIPCs, disaggregated by type of creditor, are displayed in Figure $5 .^{6}$ Both bilateral and private net loans started decreasing since the beginning of the eighties. While private net loans were negative throughout the whole period, bilateral net loans became negative in the mid nineties. Until 1997 positive long-term net loans to the HIPCs were ensured by multilateral organisations. International financial institutions played a crucial role in maintaining a positive flow of funds to the HIPCs.

Figure 5: Long-Term Net Loans \% GDP by type of creditor. HIPCs. 1970-99

Since the early nineties, transfers to the HIPCs have mainly taken the form of grants. Differently from the data on grants presented above (which come from the GDF database) Figure 6 shows the data on grants disaggregated by type of donor, which are provided by the Development Assistance Committee of the OECD, as the GDF does not contain such distinction. ${ }^{7}$ Both bilateral and multilateral grants have been rising since the seventies, but bilateral grants have been increasingly higher than multilateral grants throughout the whole period. Figure 6 also shows that grants started to decrease in 1995 (which looks like further evidence of no-additionality) while multilateral grants began to rise again in 1998.

Evidence on net loans and grants clearly shows that bilateral creditors, unlike private creditors who pulled out from HIPCs, have switched from loans to grants. Figure 6 shows that bilateral grants have continued to flow into these countries, thereby compensating for the fall of net loans. As debt service payments started exceeding new loans in 1994, this pattern suggests that bilateral grants may have freed resources to be used for the repayment of the bilateral debt.

Figure 6: Grants \% GDP by type of donors. HIPCs. 1970-99

Interestingly, among the alternative sources of funds to the HIPCs only net loans by multilateral creditors have been growing over the whole period. The increasing involvement of multilateral organisations in the debt of the HIPCs is evident from Figure 7 which shows that the rising debt held by the multilaterals substituted the debt held by other

\footnotetext{
${ }^{6}$ As data on IMF net loans were not originally included in the long term multilateral net loans we had to add them to the series.

${ }^{7}$ Data on grants from DAC include both technical cooperation grants and debt relief.
} 
creditors (however, bilateral debt still accounts for half of the total). This descriptive evidence confirms what claimed by Easterly (2001, 2002), namely that the HIPCs debt crisis developed because of the expansion of official lending. Official lenders did not seem to follow the same prudential rules as private capital, which pulled out of the HIPCs and they may have given new loans to actually enable the old loans to be paid back.

Figure 7: Long-Term External Debt \% GDP by type of creditor. HIPCs. 1970-99

This evidence raises the issue of what motivated the increasing involvement of multilateral organisations in the HIPCs debt problem. Humanitarian reasons certainly provide a possible explanation. A second explanation is that a substitution of multilateral for bilateral debt may increase the leverage of the international community on the HIPCs. Indeed, multilateral loans are conditional on the adoption of reforms and adjustment programmes and multilateral organisations are senior creditors because default on their debt may lead to the exclusion from future lending and from other forms of aid. Finally, the behaviour of multilateral creditors can be explained by "defensive lending". Multilateral organisations may have intervened with the main goal of avoiding default and thus the "embarrassment" of losses in their budgets and failure of aid policy.

\section{A Model of Net Loans and Grants Determination}

The descriptive evidence presented in the second section clearly suggests that the lending activity of governments and multilateral organisations to the HIPCs cannot be explained without a joint analysis of aid concession. More importantly, it appears that the behaviour of multilateral organisations (in the aggregate) is affected by the behaviour of the other major lenders, be they private or public. In particular, since the early 1980s, the continuous drop out of private and bilateral creditors has been offset by an increasing involvement of multilateral organisations in lending to the HIPCs. Bilateral and multilateral grants have also flowed into these countries, at least until the mid nineties, apparently to make up for the shrinking channel of bilateral credit.

This evidence leads us to examine whether there is a link between net loans and grants to the HIPCs and between the decisions of bilateral and multilateral creditors. In particular, we want to study the interactions between the lending and granting decisions of multilateral and bilateral creditors, a theme that has so far received scant attention in the empirical literature, despite the central role that it should play in the "defensive lending" hypothesis. Moreover, if such hypothesis were empirically relevant, we would expect that net loans and grants were motivated not only by the level of debt but also by the amount of debt owed to each creditor.

In the following analysis we examine the behaviour of grants and long-term loans net of principal and interest repayments from bilateral creditors and from multilateral creditors for the period 1982 to 1999. The reason we focus on this period is that the debt crisis of the early 1980s arguably marked a shift in regime. Data on loans are from Global 
Development Finance (GDF) statistics of the World Bank; data on grants disaggregated by type of donors come from the Development Assistance Committee (DAC) of the OECD and include technical cooperation.

Our definition of net loans is equal to "net flows" (i.e. the change in the external debt) in the GDF definition minus interest payments. This aggregate gives the amount of disbursements that are left to the HIPCs once they have paid for the service of their debts. Thus, we take into account the fact that most of the new credit flows back to the creditors in the form of interest and principal repayments. As we abstract from any gross lending made with the purpose of allowing the HIPCs to fulfil their maturing liabilities, we take for granted this kind of defensive lending and investigate whether more indebted countries get even greater support on top of this.

Finally, we confine our attention to long-term net loans, since the GDF database does not provide any information on creditors of short-term loans. However, we believe that long-term loans are fairly representative of the aggregate behaviour, since short-term loans have been a small share of total loans for the period under investigation.

We estimate a dynamic panel of 52 low-income countries for the period 1982 to 1999 with both country-specific effects and time effects. The sample includes 39 HIPC countries and a control group of other 13 low-income countries. This allows us to test for possible differences in the lending and granting behaviour of official institutions toward HIPC countries relative to non-HIPC countries. We had to exclude Somalia and Vietnam from the group of 41 HIPCs because of data availability in the former case and inconsistency between stocks and flows in the latter. Data availability has also limited the non-HIPC group to 13 countries, out of the 68 low-income countries listed in Table 1.

We choose a dynamic specification -i.e. we include a lag of the dependent variable among the regressors- to account for the short run dynamics of net loans and grants. The dynamic specification allows for a correct estimation of the effect of high levels of debt by controlling for the autocorrelation of net loans and grants.

The estimated equations for net loans and grants are as follows:

$$
\begin{aligned}
L_{i, t}^{j}= & b_{0}+b_{1} L_{i, t-1}^{j}+b_{2} L_{i, t-1}+b_{3} B_{i, t-1}+b_{4} G_{i, t-1}+ \\
& b_{5} Z_{i, t-1}+b_{6} C_{i}+b_{7} T_{t} \\
G_{i, t}^{j}= & c_{0}+c_{1} G_{i, t-1}^{j}+c_{2} G_{i, t-1}+c_{3} B_{i, t-1}+c_{4} L_{i, t-1}+ \\
& c_{5} Z_{i, t-1}+c_{6} C_{i}+c_{7} T_{t}+c_{8} F_{i, t-1}
\end{aligned}
$$

where $L_{i, t}^{j}$ denotes net long-term loans (relative to GDP) to country $i$ from creditor $j$ (i.e. bilateral or multilateral creditors) and $L_{i, t-1}$ is the vector of long-term net loans from the other creditors (i.e. private creditors and bilateral or multilateral creditors). The variable $G_{i, t}^{j}$ denotes grants (relative to GDP) to country $i$ from donor $j$ (i.e. bilateral or multilateral grants) and $G_{i, t}$ the grants from the other donor. Therefore we consider the interactions between creditors' decisions and between loans and grants. 
To examine the relation between aid policy and indebtedness, we consider the stock of long-term debt (relative to GDP) owed to bilateral, multilateral and private creditors and enter the three types of debt separately; i.e. $B_{i, t-1}$ is the vector of the stocks of long-term debt held by multilateral, bilateral and private creditors.

To control for the fact that grants partly includes debt reductions, in the bilateral and multilateral grant equations we add the amount of ODA debt forgiveness (relative to GDP), $F_{i, t-1}$. This variable also provides evidence on aid additionality.

In order to distinguish the "defensive lending" hypothesis from other motivations for providing loans and grants, we consider as explanatory variables the set of variables $Z_{i, t-1}$ suggested by the literature on aid and loans concession. Following the distinction made by Alesina and Dollar (2000) and Alesina and Weber (2002), we include variables that should account for the recipients' needs and the quality of their policy and institutions. The set $Z_{t-1}$ include (previous year) economic performance measured with the rate of inflation, GDP growth, and openness (constructed as the ratio of the sum of imports and exports to GDP). We also add population to the regressors, as in the aid literature it is usually found that countries with a higher population receive less aid, probably because aid is more effective when given to small countries.

These variables should actually matter both in the case loans and aid were motivated by humanitarian reasons and they would also be relevant if loans and grants were given to enhance the effectiveness of aid in stimulating development. In the latter case aid and loans are expected to positively depend on past economic performance (i.e. good policies) and on the quality of institutions. But low growth or high inflation could also lead to higher loans and grants if the latter were motivated by humanitarian reasons. To account for a rise of aid in post-war periods, we include a dummy variable that takes the value of one during the years following a conflict for a maximum of four years. ${ }^{8}$

As for the quality of institutions we consider the index of "Political Rights and Civil Liberties" (PCRL) and the indexes of Investment Profile, Law and Order, Corruption and Bureaucracy Quality from the International Country Risk Guide (ICRG). Investment Profile represents risks to investment that are not covered by the other political, economic and financial ICRG risk component; Law refers to the impartiality of the legal system while Order concerns the popular observance of the law; Corruption is assessment of corruption within the political system, which, among other consequences, represents a threat to foreign investment; finally, Bureaucracy Quality is an assessment of whether the bureaucracy has the strength and expertise to govern without drastic changes in policy or interruption of the public service. For both PRCL and the four ICRG indexes the higher the score the better the profile. ${ }^{9}$ As the ICRG indexes are available only for a subset of 38 countries, and only for the 1984 to 1999 period, we estimated our model both excluding and including such indexes.

\footnotetext{
${ }^{8}$ Collier and Hoeffler (2002) claim that aid would be considerably more effective in augmenting growth in post-conflict situations than in other situations.

${ }^{9}$ The Political Rights and Civil Liberties index values have been multiplied by (-1) as, originally, the higher the score the lower the liberties.
} 
The countries dummies $C_{i}$ are used to control for country specific characteristics. We also expect them to capture motivations related to donors' political and strategic interests, which are traditional in the aid literature, such as colonial past, religion, ethnic and geographic variables (e.g. Easterly and Levine, 2002). Finally, $T_{t}$ is a set of time dummies. Tables 4 and 5 contain all the details on our variable definitions and sources.

To understand whether a possibly positive relation of net loans and grants with the debt-to-GDP ratio arises because of "defensive lending and granting" or because of humanitarian reasons, we test whether this relation for HIPC countries is significantly different than in the case of other low-income countries. We do so by interacting the debts (relative to GDP) owed to bilateral, multilateral and private creditors with the dummy $H_{i}$ which takes the value of one in the case of a HIPC country. In particular, under the hypothesis of defensive lending (or defensive granting) the amount of loans (or grants), that a given creditor is willing to provide, should increase with the stock of debt held. ${ }^{10}$

In principle, the behaviour of official creditors and donors may differ between HIPCs and non-HIPCs also relative to the other variables in equations (1) and (2). We tested the hypothesis that the interactions of the dummy $H_{i}$ with the other regressors were zero and could not reject it except for the lagged dependent variable in the grant equation (2) for both bilateral and multilateral grants, and in the case of output growth in the multilateral grant equation. However, in the latter case, considering a different effect for HIPCs does neither affect the overall explanatory power of output growth nor the values and significance of the other coefficients. Therefore, this suggests the estimation of the following equations:

$$
\begin{aligned}
L_{i, t}^{j}= & b_{0}+b_{1} L_{i, t-1}^{j}+b_{2} L_{i, t-1}+b_{3} B_{i, t-1}+b_{4} G_{i, t-1}+ \\
& b_{5} Z_{i, t-1}+b_{6} C_{i}+b_{7} T_{t}+b_{8} H_{i} B_{i, t-1} \\
G_{i, t}^{j}= & c_{0}+c_{1} G_{i, t-1}^{j}+c_{2} G_{i, t-1}+c_{3} B_{i, t-1}+c_{4} L_{i, t-1}+ \\
& c_{5} Z_{i, t-1}+c_{6} C_{i}+c_{7} T_{t}+c_{8} F_{i, t-1}+c_{9} H_{i} F_{i, t-1}+ \\
& c_{10} H_{i} G_{i, t-1}^{j}+c_{11} H_{i} B_{i, t-1}
\end{aligned}
$$

\subsection{The estimation method}

We adopt a GLS fixed effect estimator in order to control for countries unobservables and to correct for heteroskedasticity across countries. To account for the short run dynamics of net loans and grants we include a lag of the dependent variable among the regressors. The dynamic specification allows for a correct estimation of the effect of high levels of debt by controlling for the autocorrelation of net loans and grants. Indeed, a strong dependence of net loans and grants from the level of debt in the static specification might actually

\footnotetext{
${ }^{10}$ The dummy for HIPCs cannot enter separately in the regressions because of the presence of countryspecific effects.
} 
reflect the autocorrelation of loans and grants that are typically disbursed in a number of installments over time. Without correcting for the short run dynamics, a correlation between net loans and debt could reflect a common deterministic trend. The evidence we provide on the importance of defensive lending is thus robust to the latter problem that appears to affect other results in the literature (see e.g. Frey and Schneider 1986 and Birdsall et al. 2002). The time dummies capture the contemporaneous correlations across countries.

In a typical panel, which has vastly more individuals than time periods, the inclusion of the lagged dependent variable would introduce a bias since the dependent variable, and thus the lagged dependent variable (a right hand regressor), are functions of the individual specific component of the error term. Nickell (1981) shows that in the AR(1) case the bias in estimating a dynamic fixed effects model becomes less important as T grows. Judson and Owen (1999) test the performance of the fixed effects estimator by means of Monte Carlo simulations, concentrating on panels with typical macroeconomic dimensions, i.e. small $\mathrm{N}$ and $\mathrm{T}$. Their analysis suggest that the fixed effects estimator performs well when $\mathrm{T}=30$, i.e. with a $\mathrm{T}$ dimension fairly similar to ours. Moreover, with $\mathrm{T}=18$ and $\mathrm{N}=52$ our panel can be considered a typical macro panel.

The fixed effects assumes homoskedasticity and if the assumption is not met then the estimates will be inefficient. A groupwise likelihood ratio heteroskedasticity test was performed on the residuals of the baseline model estimated by OLS. The test is chi-squared distributed with $\mathrm{N}-1$ degrees of freedom, where $\mathrm{N}$ is the number of groups in the sample, 52 countries in our case. The result of the test led to a rejection of the null hypothesis of homoskedasticity across groups for both net loans and grants regressions.

Baltagi and Li (1995) suggest an LM test for serial correlation in fixed effects models where the asymptotic distributions of the test statistics is calculated for large T. Under two alternative assumptions for the error autocorrelation structure (i.e. an $\operatorname{AR}(1)$ and a MA(1)) the null hypothesis of no serial correlation in the disturbance is rejected in two equations out of four. In any case, the size of the autocorrelation coefficient is negligible for all equations. Hence, we decided not to correct for the autocorrorrelations in the residuals and to adopt a feasible fixed effect GLS estimator, incorporating only heteroskedasticity across countries.

\section{Estimation results}

\subsection{Net Loans}

We estimate our panel of 52 countries for the period 1982 to 1999 by GLS with countryspecific effects and time effects. The hypotheses of not significance of country dummies and time dummies were indeed rejected at any reasonable significance level, as shown in Table 6 and $\%$. 
The results of the estimation of equation (3) for both bilateral and multilateral net loans (relative to GDP) are presented in Table 6. As expected, net loans are rather persistent, while most variables related to recipients' needs and economic performance are, in general, not significant. The effects of GDP growth and openness vary depending on the type of creditor considered. For instance, column 1 of Table 6 shows that a poor performance, as measured by a low GDP growth, significantly increases net loans from bilateral creditors at the $5 \%$ level. Larger flows of bilateral loans to low-growth countries can be explained by the greater needs of the recipients. Loans from bilateral creditors are also positively and significantly affected, though at the $10 \%$ level, by the openness of the receiving country, an indication of the importance of commercial ties and/or the ability to service the external debt.

Interestingly, and consistently with other results in the literature, economic performance does appear to play a role in multilateral lending. ${ }^{11}$ Column 3 shows that GDP growth has a positive effect on multilateral loans and this effect is significant at the $5 \%$ level. By contrast, openness does not significantly affect multilateral loans. Finally, both bilateral and multilateral loans are neither affected by "Political Rights and Civil Liberties" nor by per-capita GDP. A "post war" dummy is also not significant in both regressions, showing that loans from either source are not substantially higher in the four years following the end of a conflict.

The important evidence concerns the effect of the debt (relative to GDP), that we divide into bilateral, multilateral and private debt depending on the type of the holder. As we focus on the behavior of bilateral creditors, column 1 shows that in the case of countries which are not HIPCs (for which debt sustainability is not a problem) the coefficients on the debt ratios are all negative but not significant. In the case of HIPCs, instead, a higher debt owed to bilateral creditors significantly reduces their net loans: the coefficient on the variable that interacts the bilateral debt with the dummy for being a HIPC is negative and significant at the $1 \%$ level. Therefore, bilateral creditors clearly reduce their loans as their debt exposure increases and significantly so in the case of highly indebted countries. Importantly, a credit restrain is induced by a higher stock of bilateral debt, while the amount of debt held by multilateral and private creditors does not significantly affect the behaviour of bilateral creditors.

A completely different picture emerges as we look at the lending policy of multilateral creditors, in column 3. In fact, multilateral organisations are strikingly more generous with high-debt countries than with low-debt countries. More specifically, the amount of loans given to non-HIPCs falls as the debt owed to multilateral organisation increases, as shown by a coefficient on multilateral debt that is negative and significant at the $1 \%$ level. This effect disappears in the case of HIPCs: the coefficient of the variable that interacts multilateral debt with a dummy for being HIPC is positive and significant at the $1 \%$ level. This effect is quantitatively important: a $10 \%$ increase of multilateral debt

\footnotetext{
${ }^{11}$ Burnside and Dollar (2000), for example, find that the quality of a country's policy has only a small impact on the allocation of aid, at least for bilateral donors which seem more respondent to donor interests. On the contrary, multilateral aid is allocated to countries with better policies.
} 
in terms of GDP across all countries reduces net loans to non-HIPCs by $0.4 \%$ of GDP (more than it does with HIPCs) in the short run and by $0.9 \%$ of GDP in the long run.

This non-linear relation between multilateral loans and multilateral debt suggests that, at high levels of debt, the lending policy of multilateral creditors is motivated by a concern for debt sustainability and strongly supports the hypothesis of defensive lending. More importantly, debt ownership appears to be an important determinant of the lending decisions of multilateral creditors. Indeed, their loans to HIPCs significantly increase with the stock of multilateral debt, while the impact of both bilateral and private debt is not significant. This evidence clearly points to defensive lending as the main motivation for the behavior of multilateral organisations. We should stress here that this kind of "perverse" incentive is even more serious when associated to the multilaterals that should, at the same time, both lend and monitor the actual implementation of the reforms (Ramcharan, 2002). However, to mitigate this conclusion it could also be that case that the element of "defense" is not necessarily related to the multilateral self-interest but it could also depend on their concern for financial stability.

Finally, we examine the interaction between loans and grants. The estimated regressions show that net loans from both bilateral and multilateral creditors are not significantly related to previous-year grants from the same group of creditors (nor to loans by other creditors). Bilateral creditors actually appear to reduce loans to countries that receive more grants from bilateral sources but this effect is not statistically significant. The lending policy of multilateral organisations is also quantitatively unrelated to their aid policy. This evidence suggests that, in spite of the concessional nature of most loans to low-income countries, in general such loans are not viewed as strong substitutes of grants by their givers. Incidentally, this supports our strategy of considering loans and grants separately in the empirical analysis.

The interesting result that emerges from the analysis of the interaction between multilateral and bilateral policy is the significant flow of multilateral loans into countries that have received grants from bilateral donors in the previous year. Indeed, column 3 shows that the effect of bilateral grants on multilateral loans is significant at the $1 \%$ level. This positive relation might reflect the concessional nature of multilateral loans that could be provided to complement the aid policy of bilateral donors, but such explanation is somewhat inconsistent with the evidence of the little role played by the recipients' needs in motivating multilateral loans. The analysis of the determinants of bilateral and multilateral grants will shed more light on this issue. ${ }^{12}$

Finally, we tested whether the results of the estimation of equation (3) are robust to the exclusion of non significant variables by sequentially excluding these variables. Columns 2 and 4 report a more parsimonious specification for the equations of bilateral and multilateral net loans, respectively. As can be seen by comparing columns 1 and 2 , the coefficients of the variables explaining bilateral loans are remarkably stable across

\footnotetext{
${ }^{12}$ We tested whether the relation between multilateral net loans and bilateral grants differs across HIPCs and non-HIPCs, but the hypothesis that the coefficients of bilateral grants is the same for the two groups of countries could not be rejected even at the $10 \%$ significant level.
} 
specifications. ${ }^{13}$ The main changes concern openness that is now significant at the $5 \%$ level, and GDP growth that is significant at the $1 \%$ level. With regard to multilateral loans no significant differences either in the size of the coefficients or in their significance emerge across the two specifications, as shown by comparing columns 3 and 4 .

\subsection{Grants}

We now turn to the analysis of the determinants of bilateral and multilateral grants relative to GDP. Estimates of the grant equations (4) are presented in Table 7 for both bilateral and multilateral grants. The explanatory variables also include debt forgiveness to control for the fact that debt reductions, though classified as grants in the OECD statistics, do not necessarily free additional resources to be used by debtor countries.

The high and significant coefficient on the lagged dependent variable in the bilateral grants equation (see column 1) shows that bilateral grants are highly persistent. More important, the flow of grants that HIPCs receive from bilateral donors appears significantly more persistent than that received by non-HIPCs, as shown by the significant interaction between the HIPC dummy and the lagged dependent variable. This result is an indication of the low quality of aid allocation: for any level of aid received in the past, HIPCs tend to receive more aid today compared to non-HIPCs, despite their poorer economic performance. As observed by Easterly (2002), aid to HIPCs tends to perpetuate itself. The economic relevance of this effect is however mild, as the coefficient on lagged grants for HIPCs is only 15\% higher than for non-HIPCs. Multilateral grants exhibit a much lower persistence compared to bilateral grants. Even in this case, however, grants received by HIPCs are more persistent, as shown by the significant interaction between the HIPC dummy and the lagged dependent variable. ${ }^{14}$

Grants from bilateral donors are not significantly affected by variables related to recipients' needs and economic performance. Column 1 shows that only "Political Rights and Civil Liberties" (PRCL) have a positive and significant effect, though at the 10\% level. Focusing on the behaviour of multilateral donors, column 3 shows that a low growth performance, as measured by a low GDP growth, significantly increases the flow of grants at the $1 \%$ level. The strong intervention of international organisations in low growth environments is evidence of the importance of recipients' need motivations in their aid policy. Interestingly, and contrary to other results in the empirical literature (e.g. Burnside and Dollar, 2000, Collier and Dollar, 2002), economic performance, as measured by openness and inflation, does not seem to be a relevant factor of multilateral aid.

A "post war" dummy displays a negative effect on both bilateral and multilateral grants, contrary to expectations, though it is significant only in the bilateral grants equa-

\footnotetext{
${ }^{13}$ The exclusion of private debt from the equation of bilateral loans does not change this conclusion.

${ }^{14}$ As the coefficient on lagged grants for HIPCs is about $20 \%$ higher than that for non-HIPCs the effect is similar to the case of bilateral grants even if its significance is lower (at $10 \%$ level).
} 
tion. The fact that grants from either sources are, if anything, lower in the four years following the end of a conflict is further evidence of a poor allocation of aid. ${ }^{15}$

The important evidence concerns the effect of the level of debt (relative to GDP). Column 1 shows that bilateral donors tend to reduce the amount of grants given to nonHIPC low-income countries as their debt increase. This effect is independent of the holder of the debt, but it is not significant. On the contrary, HIPCs receive more grants from bilateral donors as bilateral debt increases: the coefficient of the variable that interacts the HIPC dummy with bilateral debt is positive and significant at the $1 \%$ level. This effect is economically relevant: while in the case of non-HIPCs a debt increase has no significant effect, in the case of HIPCs an increase of bilateral debt of $10 \%$ of GDP increases grants by almost $0.2 \%$ in the short run and by $0.5 \%$ of GDP in the long run.

Evidence of preferential treatment for HIPCs is even stronger when we look at the estimated equation for multilateral grants in column 3. The amount of grants given to non-HIPCs falls as the debt owed to multilateral creditors increases, as shown by a coefficient on multilateral debt that is negative and significant at the $1 \%$ level. This effect disappears in the case of HIPCs where the coefficient of the variable that interacts multilateral debt with a dummy for being a HIPC is positive and significant at the $1 \%$ level. The long run impact of a higher debt is however lower than in the case of bilateral grants: a 10\% increase of multilateral debt in terms of GDP across all countries reduces multilateral grants to non-HIPCs by $0.2 \%$ of GDP more than it does in HIPCs in the short run and by $0.3 \%$ of GDP in the long run.

Therefore, the aid policy of both donor groups towards HIPC debtors is significantly different from their policy towards non-HIPCs debtors. Evidence of a non-linear relation between grants and debt suggests that, at high levels of debt, a concern for debt sustainability might motivate the aid policy of both bilateral and multilateral donors, thereby supporting the hypothesis of "defensive granting". Importantly, debt ownership debt seems an important determinant of the aid policy of both bilateral and multilateral donors. The amount of grants that each donor group provides to HIPCs significantly increases with the stock of debt held by that group, while the impact of the debt held by the other creditors is not significant. This evidence provides further support to the hypothesis of defensive granting. Because a positive relation between grants and debt only emerges in the case of HIPCs, the hypothesis of 'defensive granting' appears to offer a more convincing explanation than humanitarian motivations for the positive link between aid and debt. In fact, even if HIPCs are in more need than other low-income countries, the presence of country-specific effects should control for this motivation of aid.

The results in column 1 show that grants by bilateral donors are independent of previous-year grants from multilateral organisations but tend to flow into countries that have received net loans from these institutions (multilateral loans are significant at the $1 \%$ level). A tentative explanation for this positive relation is that grants are usually given as

\footnotetext{
${ }^{15}$ To account for an eventual fall of aid during war years we also tried to include a dummy variable taking the value of one during the years of war but this was not significant neither in the net loans nor in the grants equations.
} 
a part of a broader adjustment programme coordinated by multilateral organisations (at least this is the case for programme aid or budget support). The adoption of an IMF or World Bank programme could actually work either as a pre-condition for receiving grants or it could signal a sound institutional and economic environment conducive to growth. As multilateral grants are concerned, we find that receiving a bilateral grant increases the probability to obtain a multilateral grant in the following year, where this impact is significant at the $1 \%$ level. The two pieces of evidence are consistent with the results presented in Table 6 , namely that multilateral creditors significantly direct their loans to countries benefiting from bilateral grants.

The picture that emerges from the analysis of the interactions of bilateral and multilateral institutions is one where bilaterals try to decrease their debt exposure in HIPCs by substituting grants for loans while multilateral organisations makes more loans and grants available to these countries to help them escape the debt sustainability problem. This may explain why both grants and loans of multilateral organisations strongly react to bilateral grants. Moreover, while multilateral organisations follow the same aid and lending strategy towards HIPCs, bilateral donors provide HIPCs with more grants while reducing their net loans. This evidence suggests that, as the debt problem worsened, bilateral donors may have used grants as substitutes for loans. It is worth noting that this exchange of grants for loans is linked to the stock of bilateral debt while there is no significant relation between bilateral grants and net loans. These results thus raise the concern that, in the case of HIPCs, bilateral aid has been used (or has freed up resources) to service the external debt.

As the aid additionality issue is concerned, we find that the coefficient of debt forgiveness in the bilateral grants equation is significant at $5 \%$ level and not significantly different for HIPCs. The fact that this coefficient is negative and greater than one in absolute value shows that debt forgiveness substantially reduces the flow of grants in the following year, independently of the type of country considered. The substitution of debt reductions for money transfers is a cause of concern since it is likely to reduce the amount of resources available to low-income countries (i.e. independently of being HIPCs or not).

We also tested whether the results of the estimation of the grant equation (4) are robust to the exclusion of non-significant variables by sequentially excluding these variables. Columns 2 and 4 of Table 7 report a more parsimonious specification for the equations of bilateral and multilateral grants, respectively. As can be seen by comparing columns 1 and 2, former results for bilateral grants are confirmed by the new estimates. If anything, the new specification implies a greater coefficient for the interaction of the HIPC dummy with bilateral debt. On the contrary, the new equation estimated for multilateral grants presents a main difference relative to the baseline specification. As seen by comparing columns 3 and 4 , the coefficient on private debt is now positive and significant at the $1 \%$ level. Except for this role of private debt in attracting multilateral grants, there are no other significant differences either in the size of the coefficients of the other variables or in their significance.

Finally, since the quality of the institutions has recently been found as a key aspect in 
determining economic development (see, among others, Knack and Kneefer, 1995, Mauro, 1995, Easterly and Levine, 2002) we would expect that a good quality of institutions be a potential factor motivating aid allocation. To test for this we have augmented our specification with the indexes of Bureaucracy Quality, Corruption, Law and Order and Investment Profile from the ICRG. Since such indexes are probably highly correlated we use each indicator in isolation. The introduction of these proxies of "good quality" of institutions comes at the cost of restricting our sample to only 38 countries and to the period 1984 to 1999, but produces disappointing results as the coefficients of the indexes of institutional quality are never significant. This finding can be explained with the fact that our sample of countries is rather homogeneous with respect to the (poor) quality of their institutions. Since institutions do not appear to be a factor in aid allocation across HIPCs countries, results obtained for the full sample of 52 countries appear more reliable.

\subsection{Selecting HIPCs}

One may actually worry that there is a (sub)sample selection bias because HIPCs were classified as such only in 1996 (on the basis of data for the year 1993) and not at the beginning of the sample. It is, however, worth noting that our results imply that, if HIPCs had not been highly indebted at the beginning of the sample, they could not have become highly indebted, and thus classified as HIPCs, because of defensive lending. In fact, had the debt ratio of HIPCs been lower at the beginning of the sample, they would have received lower loans from the international community.

In order to check the robustness of our results, we re-estimated equations (3) and (4) using another dichotomic variable as a proxy of high indebtedness in place of the HIPC dummy. Specifically, we constructed a dummy called HDEGC (high debt to export and to GDP) which is equal to one (and remain such) once a country reaches either a value of its debt to export ratio greater than $220 \%$ or a value of its debt to GDP ratio greater than $80 \%$ in the sample period. These criteria are similar to those used to classify a low-income country as HIPC in 1996, namely a value of the 1993 present value of debt to exports higher than $220 \%$ or present value of debt to GNP higher than $80 \%$ (e.g. see The Initiative for Heavily Indebted Poor Countries Review and Outlook, 1998). ${ }^{16}$

The results of the estimation of the equations for bilateral and multilateral net loans and grants, using the HDEGC dummy in place of the HIPC dummy, are presented in columns 1 and 2 of Table 8. Previous results for both bilateral and multilateral loans are generally confirmed by the new estimates. As shown in column 1, most variables related to recipients' needs and economic performance do not significantly affect bilateral loans, except for GDP growth and the degree of openness. More important, a higher stock of bilateral debt still appears to reduce bilateral net loans, as the coefficient on the bilateral debt is marginally significant at the $10 \%$ level. However, it is worth noting that evidence of a negative relation between net loans and debt is independent of the degree of

\footnotetext{
${ }^{16}$ The original list of HIPCs also included nine countries that had received concessional rescheduling from Paris Club creditors or were potentially eligible for such rescheduling.
} 
indebtedness, as captured by the HDEGC dummy. In fact, the interaction of the HEDG dummy with bilateral debt is not significant, unlike for estimates using the HIPC dummy.

As multilateral loans are concerned, the results presented in column 2 confirm the preferential treatment obtained by high-debt countries relative to low-debt countries. In particular, while a higher share of debt owed to multilateral creditors tends to reduce the amount of their loans to low-debt countries, the opposite holds true in the case of high-debt countries as defined by the HDEGC dummy. Indeed, a higher multilateral debt significantly increases the amount of loans given to the former group at the $1 \%$ level. This effect disappears in the case of high-debt countries; the coefficient on the interaction of the HDEGC dummy with multilateral debt is positive and significant at the $5 \%$ level. This evidence still points to defensive lending as the main motivation for the behavior of multilateral creditors.

The results of the estimation of the equations for bilateral and multilateral grants using the HDEGC dummy are presented in columns 3 and 4 of Table 8. Under the new classification of highly indebted countries, there is no evidence of defensive granting. As shown in column 3, bilateral grants appear to be unrelated to any debt variable either taken in isolation or interacted with the HDEGC dummy. Column 4 shows that multilateral grants significantly decrease with the stock of multilateral debt but this effect is independent of the country group: the interaction of the HDEGC dummy with multilateral debt is positive but not significant.

Therefore, while we find further evidence of defensive lending by multilateral organisations, the hypothesis of defensive granting is not supported by the new classification of highly indebted countries. However, we have shown above that HIPCs did benefit of a preferential treatment from official donors as the amount of grants they received was increasing with their debt level. This suggests that such a preferential treatment may have been motivated by other specific characteristics of HIPCs than the sheer size of their debt. Following Easterly (2002), we may think that the selection of HIPCs is justified by the fact that they are the countries the official institutions targeted their efforts to. To the extent that this selection was not only based on debt sustainability indicators, but also included countries that had received concessional rescheduling from Paris Club creditors (see footnote 16), our results would reflect these additional motivations and point to the existence of 'selective defensive granting'.

\section{Conclusions}

In this paper we have examined the determinants of net loans and grants to low-income countries, focusing on the highly indebted and poor ones. We estimate a dynamic panel of 52 low-income countries, for the period 1982 to 1999, by GLS with country-specific effects and time effects.

We find that a higher level of bilateral debt reduces bilateral net loans to HIPCs, while 
multilateral creditors appear strikingly more generous in the case of HIPCs (contrary to the results of Birdswall et al. 2002 who find bilateral creditors more responsible for low selectivity). In particular, while a higher stock of debt owed to multilateral creditors tends to reduce the amount of their loans to non-HIPCs, this effect disappears in the case of HIPCs. The amount of loans received by HIPCs increases, compared to non-HIPCs, with their level of multilateral debt. This evidence points to defensive lending as the main motivation for the behaviour of multilateral organisations where this kind of perverse incentive is even more serious when associated to the multilaterals that should, at the same time, both lending and monitoring the actual implementation of the reforms.

The aid policy of both bilateral and multilateral donors also appears more generous with HIPC than with non-HIPC countries, thereby supporting the hypothesis of "defensive granting". The amount of grants that each donor type provides to HIPCs significantly increases, compared to non-HIPCs, with its corresponding debt share.

Therefore, the results of our analysis shows that the net transfers that HIPCs have received, compared to non-HIPCs, have been increasing with their level of debt. Greater net transfers have taken the form of loans from multilateral organisations and grants in exchange for loans from bilateral institutions. As the HIPC dummy stands for an indicator of high debt, this evidence suggests that HIPCs have kept receiving a large amount of net resources just because of their high degree of indebtedness, thereby supporting both the hypothesis of defensive lending and granting.

Finally, as the aid additionality issue is concerned, we find a significant coefficient of debt forgiveness in the bilateral grants equation, independently of the type of country considered. The substitution of debt reductions for net loans is a cause of concern since it is likely to reduce the amount of resources available to all low-income countries, that is including those countries which are not under scrutiny for the debt relief initiative.

In terms of policy implications there is a main conclusion that we can draw from our analysis. Since the concern for keeping the debt sustainable (or more generally the need to avoid a debt crisis) seems to have been the key issue of HIPCs (multilateral) creditors and donors, then a strong debt stock reduction should encourage a greater selectivity in assigning grants and loans to countries in need. More selectivity, in turn, would provide debtors with better incentives, since they would not anticipate anymore that lenders would lend them anyway.

On this respect the HIPCs Initiative, which for the first time include multilateral creditors in the analysis, has the merit to provide multilaterals with further incentives in being selective when approving their loans (i.e. by making them paying a price for the debt reduction for the first time).

Bilateral donors would also be encouraged towards a greater use of selectivity in their grants assignment by a reduced debt stock. Actually, in the latter case, the evidence we find against the debt additionality hypothesis could actually suggest that grants would strongly decrease just as a direct consequence of the debt reduction. But, at least for the multilaterals, this caveat should not apply. 


\section{References}

[1] Alesina, A.,.Dollar, D., 2000. Who gives foreign aid to whom and why? Journal of Economic Growth 5, 33-63.

[2] Alesina, A.,.Weder, B., 2002. Do corrupt government receive less foreign aid. American Economic Review, 92.

[3] Baltagi, B., Li, Q., 1995. Testing AR(1) against MA(1) disturbances in error component model. Journal of Econometrics 68.

[4] Birdall, N., Claessens, S., Diwan, I., 2002. Policy Selectivity Foregone: Debt and Donor Behaviour in Africa. Center for Global Development Working Paper No. 17.

[5] Burnside, C., Dollar, D., 2000. Aid, Policies and Growth. American Economic Review $90,847-868$.

[6] Cohen, D., 2001. The HIPC Initiative: true and false promises. CEPR Discussion Paper Series No. 2632.

[7] Collier, P., Dollar, D., 2002. Aid Allocation and Poverty Reduction. European Economic Review 46, 1475-1500.

[8] Collier, P.,.Hoeffler, A., 2002. Aid, Policy and Growth in Post-Conflict Societies. World Bank Policy Research Working Paper No. 2902.

[9] Devarajan, S., Rajkumar, A.S., Swaroop, V., 1999. What Does Aid to Africa Finance? Development Research Group, World Bank, mimeograph.

[10] Development Committee (Joint Ministerial Committee of the Boards of Governors of the Bank and the Fund), 1998. The Initiative for Heavily Indebted Poor Countries Review and Outlook.

[11] Easterly, W., 2002. How did highly indebted poor countries become highly indebted? Reviewing two decades of debt relief. World Development 30, 1677-1696.

[12] Easterly, W., 2001. The Elusive Quest for Growth. Economists' Adventures and Misadventures in the Tropics. MIT Press.

[13] Easterly, W., Levine, R., 2002. Tropics, germs and crops: how endowments influence economic development. NBER Working Paper No. 9106

[14] Frey, B.S., Schneider, F., 1986. Competing Models of Internationale Lending Activity. Journal of Development Economics 20, 225-245.

[15] Gleditsch, N.P., Wallensteen, P., Eriksson, M., Sollenberg, M., Strand, H., 2002. Armed Conflict 1946-2001: A New Dataset. Journal of Peace Research 39, 615637. 
[16] Judson, R.A., Owen, A.L., 1999. Estimating dynamic panel data models: a guide for macroeconomists. Economic Letters 65, 9-15.

[17] Knack, S., Keefer, P., 1995. Institutions and Economic Performance: Cross Country Tests Using Alternative Institutional Models. Economics and Politics 7, 207-227.

[18] Mauro, P., 1995. Corruption and Growth. Quarterly Journal of Economics 110, 681712.

[19] Policy and Operations Evaluation Department (2003) "Results of International Debt Relief." IOB Evaluations No. 292, Dutch Ministry of Foreign Affairs.

[20] Neumayer, E., 2002. Is Good Governance Rewarded? A Cross-national Analysis of Debt Forgiveness. World Development 30, 913-930.

[21] Nickell, S.J., 1981. Biases in Dynamic Models with Fixed Effects. Econometrica 49, 802-816.

[22] Ramcharan, R., 2002. IMF Surveillance and Lending: Separating the Church from the State. IMF, mimeograph.

[23] Renard, R., Cassimon, D., 2001. On the Pitfalls of Measuring Aid. WIDER Discussion Paper No. 2001/69. 
Table 1: List of all low income countries

1) Afghanistan

2) Angola

3) Armenia

4) Azerbaijan

5) Bangladesh

6) Benin

7) Bhutan

8) Bolivia

9) Burkina Faso

10) Burundi

11) Cambodia

12) Cameroon

13) Central African Rep.

14) Chad

15) Comoros

16) Congo, Dem. Rep. of

17) Congo, Republic of

18) Côte d'Ivoire

19) Eritrea

20) Ethiopia

21) Gambia, The

22) Georgia

23) Ghana

24) Guinea

25) Guinea-Bissau

26) Guyana

27) Haiti

28) Honduras

29) India

30) Indonesia

31) Kenya

32) Korea DPR

33) Kyrgyz Republic

34) Lao People's Dem.Rep
35) Lesotho

36) Liberia

37) Madagascar

38) Malawi

39) Mali

40) Mauritania

41) Moldova

42) Mongolia

43) Mozambique

44) Myanmar

45) Nepal

46) Nicaragua

47) Niger

48) Nigeria

49) Pakistan

50) Rwanda

51) São Tomé \& Príncipe

52) Senegal

53) Sierra Leone

54) Solomon Islands

55) Somalia

56) Sudan

57) Tajikistan

58) Tanzania

59) Togo

60) Turkmenistan

61) Uganda

62) Ukraine

63) Uzbekistan

64) Vietnam

65) Yemen, Republic of

66) Zambia

67) Zimbabwe

68) Lesotho

Source: World Bank, GDF CD-ROM, 2001 
Table 2: List of 13 low income Countries

Bangladesh

Bhutan

Cambodia

Comoros

Haiti

India

Indonesia

Lesotho

Nepal

Nigeria

Pakistan

Solomon Islands

Zimbabwe 
Table 3: List of 41 Highly Indebted Poor Countries

Angola

Benin

Bolivia

Burkina Faso

Burundi

Cameroon

Chad

Central African Republic

Congo Dem Republic

Congo Republic

Cote d'Ivoire

Ethiopia

Gambia

Ghana

Guinea

Guinea-Bissau

Guyana

Honduras

Kenya

Lao PDR

Liberia

Madagascar

Malawi

Mali

Mauritania

Mozambique

Myanmar

Nicaragua

Niger

Rwanda

Sao Tome and Principe

Senegal

Sierra Leone

Somalia

Sudan

Tanzania

Togo

Uganda

Vietnam

Yemen

Zambia

Source: HIPCs Initiative country documents, IMF and WB. 
Table 4: Variables definition

\begin{tabular}{lll}
\hline \hline Variable & Definition & Units \\
\hline Multilateral Grants & Multilateral Grants & Ratio to GDP \\
Bilateral Grants & Bilateral Grants & Ratio to GDP \\
Multilateral Net Loans & Mul Net Loan+IMF Net Loans & Ratio to GDP \\
Bilateral Net Loans & Bilateral Net Loan & Ratio to GDP \\
Private Net Loans & Private Net Loan & Ratio to GDP \\
Population & Population & Billions units \\
Pc-GDP & Gross Domestic Product & Ratio to Population (thousands units) \\
Inflation & Consumer Price Index & Annual Rate of change \\
Gr-GDP & Real GDP growth & Annual Rate of change \\
Openness & Imports+Exports & Ratio to GDP \\
PRCL & Political Right\&Civil Liberties & Average Index \\
Multilateral Debt & Long term Mul Debt+IMF Debt Ratio to GDP \\
Bilateral Debt & Long term Bilateral Debt & Ratio to GDP \\
Private Debt & Long term Bilateral Debt & Ratio to GDP \\
Debt Forgiven & Debt Forgiveness & Ratio to GDP \\
Bureaucracy quality & Bureaucracy quality & Index \\
Corruption & Corruption & Index \\
Inv Profile & Investment profile & Index \\
Law \& Order & Law \& Order & Index \\
Dummy Post War & Years of post conflict & Binary \\
\hline \hline
\end{tabular}


Table 5: Data source

\begin{tabular}{ll}
\hline \hline Variable & Source \\
\hline Bilateral \& Multilateral Grants & DAC (OECD) \\
Debt Forgiveness & DAC (OECD) \\
Total Grants & Global Development Finance (GDF) \\
Multilateral Net Loans & Global Development Finance (GDF) \\
Bilateral Net Loans & Global Development Finance (GDF) \\
Private Net Loans & Global Development Finance (GDF) \\
Population & International Financial Statistics (IFS) \\
Pc-GDP & World Economic Outlook (WEO) \\
Inflation & World Economic Outlook (WEO) \\
Gr-GDP & World Economic Outlook (WEO) \\
Openness & World Development Indicators (WDI) \\
Political Rights and Civil Liberties & Freedom House \\
Multilateral Debt & Global Development Finance (GDF) \\
Bilateral Debt & Global Development Finance (GDF) \\
Private Debt & Global Development Finance (GDF) \\
Bureaucracy quality & ICRG \\
Corruption & ICRG \\
Inv Profile & ICRG \\
Law \& Order & ICRG \\
Dummy War/Post War & Gleditsch et al. (2002) \\
\hline \hline
\end{tabular}


TABLE 6: Net Loans with interactions with HIPC

\begin{tabular}{|c|c|c|c|c|}
\hline & $\begin{array}{l}\text { Bilateral } \\
\text { Net Loans }\end{array}$ & $\begin{array}{l}\text { Bilateral } \\
\text { Net Loans }\end{array}$ & $\begin{array}{l}\text { Multilateral } \\
\text { Net Loans }\end{array}$ & $\begin{array}{l}\text { Multilateral } \\
\text { Net Loans }\end{array}$ \\
\hline Population & $\begin{array}{l}0.0229^{* *} \\
(2.073)\end{array}$ & $\begin{array}{l}0.0257^{* *} \\
(2.208)\end{array}$ & $\begin{array}{l}-0.0243 \\
(1.610)\end{array}$ & $\begin{array}{c}-0.0231 \\
(1.620)\end{array}$ \\
\hline Per capita GDP $(-1)$ & $\begin{array}{l}-0.0031 \\
(1.282)\end{array}$ & & $\begin{array}{l}-0.0013 \\
(0.445)\end{array}$ & \\
\hline Inflation (-1) & $\begin{array}{l}0.0001 \\
(1.224)\end{array}$ & & $\begin{array}{l}0.00001 \\
(0.393)\end{array}$ & \\
\hline GDP Growth (-1) & $\begin{array}{l}-0.0192^{* *} \\
(2.459)\end{array}$ & $\begin{array}{l}-0.0195^{* * *} \\
(2.599)\end{array}$ & $\begin{array}{l}0.0158^{* *} \\
(2.040)\end{array}$ & $\begin{array}{l}0.0183^{* *} \\
(2.358)\end{array}$ \\
\hline Openness $(-1)$ & $\begin{array}{l}0.0055^{*} \\
(1.820)\end{array}$ & $\begin{array}{l}0.0062^{* *} \\
(2.397)\end{array}$ & $\begin{array}{l}0.0005 \\
(0.216)\end{array}$ & \\
\hline PRCL & $\begin{array}{l}-0.0003 \\
(0.929)\end{array}$ & & $\begin{array}{l}0.0002 \\
(0.487)\end{array}$ & \\
\hline Multilateral Debt (-1) & $\begin{array}{l}-0.0035 \\
(0.392)\end{array}$ & & $\begin{array}{l}-0.0686^{\star * *} \\
(6.295)\end{array}$ & $\begin{array}{l}-0.0673^{* * *} \\
(6.833)\end{array}$ \\
\hline Bilateral Debt $(-1)$ & $\begin{array}{l}-0.0019 \\
(0.849)\end{array}$ & $\begin{array}{l}-0.0016 \\
(0.720)\end{array}$ & $\begin{array}{l}-0.0007 \\
(0.332)\end{array}$ & \\
\hline Private Debt (-1) & $\begin{array}{l}-0.0237 \\
(1.505)\end{array}$ & $\begin{array}{l}-0.0201 \\
(1.377)\end{array}$ & $\begin{array}{l}0.0081 \\
(0.734)\end{array}$ & \\
\hline HIPC x Multilater. Debt $(-1)$ & $\begin{array}{l}0.0027 \\
(0.307)\end{array}$ & & $\begin{array}{l}0.0433^{* * *} \\
(4.103)\end{array}$ & $\begin{array}{l}0.0449^{* * *} \\
(4.874)\end{array}$ \\
\hline HIPC x Bilateral Debt (-1) & $\begin{array}{l}-0.0181^{* * *} \\
(4.487)\end{array}$ & $\begin{array}{l}-0.0142^{* * *} \\
(4.082)\end{array}$ & $\begin{array}{l}0.0034 \\
(0.985)\end{array}$ & \\
\hline HIPC x Private Debt $(-1)$ & $\begin{array}{l}0.0257 \\
(1.543)\end{array}$ & $\begin{array}{l}0.0231 \\
(1.505)\end{array}$ & $\begin{array}{l}-0.0102 \\
(0.883)\end{array}$ & \\
\hline Multilateral Net Loans $(-1)$ & $\begin{array}{l}0.0246 \\
(1.160)\end{array}$ & & $\begin{array}{l}0.5116^{\text {*** }} \\
(17.292)\end{array}$ & $\begin{array}{l}0.5124^{* * *} \\
(17.752)\end{array}$ \\
\hline Bilateral Net Loans (-1) & $\begin{array}{l}0.5014^{* * *} \\
(16.572)\end{array}$ & $\begin{array}{l}0.5190^{* * *} \\
(18.104)\end{array}$ & $\begin{array}{l}0.0115 \\
(0.530)\end{array}$ & \\
\hline Private Net Loans $(-1)$ & $\begin{array}{l}0.0223 \\
(0.870)\end{array}$ & & $\begin{array}{l}0.0268 \\
(1.531)\end{array}$ & \\
\hline Multilateral Grants (-1) & $\begin{array}{l}-0.0011 \\
(0.086)\end{array}$ & & $\begin{array}{l}-0.0092 \\
(0.777)\end{array}$ & \\
\hline Bilateral Grants (-1) & $\begin{array}{l}-0.0091 \\
(0.677)\end{array}$ & & $\begin{array}{l}0.0875^{\text {*** }} \\
(6.550)\end{array}$ & $\begin{array}{l}0.0861^{* * *} \\
(6.788)\end{array}$ \\
\hline Dummy Post War & $\begin{array}{l}-0.0005 \\
(0.250)\end{array}$ & & $\begin{array}{l}-0.0013 \\
(0.718)\end{array}$ & \\
\hline Constant & $\begin{array}{l}0.0025 \\
(0.405) \\
\end{array}$ & $\begin{array}{l}0.0025 \\
(0.572) \\
\end{array}$ & $\begin{array}{l}-0.00004 \\
(0.009) \\
\end{array}$ & $\begin{array}{l}-0.0020 \\
(0.975) \\
\end{array}$ \\
\hline Observations & 936 & 936 & 936 & 936 \\
\hline Number of countries & 52 & 52 & 52 & 52 \\
\hline Number of years & 18 & 18 & 18 & 18 \\
\hline SE of regression & 0.0257 & 0.0256 & 0.0259 & 0.0257 \\
\hline SE of Dependent variable & 0.0386 & 0.0386 & 0.0388 & 0.0388 \\
\hline Time Dummies & Chi2(17)=37.06 & Chi2(17)=59.69 & Chi2(17)=30.73 & Chi2(17)=34.92 \\
\hline joint significance test & Prob $>$ chi $2=0.003$ & Prob $>$ chi $2=0.000$ & Prob $>$ chi $2=0.022$ & Prob $>$ chi2 $=0.006$ \\
\hline Country Dummie & Chi2(51)=75.05 & Chi2(51) $=70.36$ & Chi2(51)=131.20 & Chi2(51) $=155.15$ \\
\hline joint significance test & Prob $>$ chi $2=0.016$ & Prob $>$ chi $2=0.037$ & Prob $>$ chi $2=0.000$ & Prob $>$ chi $2=0.000$ \\
\hline
\end{tabular}


TABLE 7 : Grants with interactions with HIPC

\begin{tabular}{|c|c|c|c|c|}
\hline & Bilateral Grants & Bilateral Grants & Multilateral Grants & Multilateral Grants \\
\hline Population & $\begin{array}{l}-0.0160 \\
(0.613)\end{array}$ & & $\begin{array}{l}-0.0077 \\
(0.470)\end{array}$ & \\
\hline Per capita GDP $(-1)$ & $\begin{array}{l}-0.0056 \\
(1.529)\end{array}$ & $\begin{array}{l}-0.0060^{*} \\
(1.833)\end{array}$ & $\begin{array}{l}-0.0026 \\
(1.385)\end{array}$ & $\begin{array}{l}-0.0027^{*} \\
(1.668)\end{array}$ \\
\hline Inflation $(-1)$ & $\begin{array}{l}0.00002 \\
(0.338)\end{array}$ & & $\begin{array}{l}0.00002 \\
(0.791)\end{array}$ & \\
\hline GDP Growth (-1) & $\begin{array}{l}0.0148 \\
(1.132)\end{array}$ & & $\begin{array}{l}-0.0272^{* * *} \\
(4.472)\end{array}$ & $\begin{array}{l}-0.0327^{* * *} \\
(6.082)\end{array}$ \\
\hline Openness $(-1)$ & $\begin{array}{l}-0.0007 \\
(0.209)\end{array}$ & & $\begin{array}{l}-0.0007 \\
(0.443)\end{array}$ & \\
\hline PRCL & $\begin{array}{l}0.0009^{*} \\
(1.672)\end{array}$ & $\begin{array}{l}0.0010^{*} \\
(1.871)\end{array}$ & $\begin{array}{l}-0.0003 \\
(1.448)\end{array}$ & \\
\hline Multilateral Debt $(-1)$ & $\begin{array}{l}-0.0164 \\
(1.170)\end{array}$ & $\begin{array}{l}-0.0118^{*} \\
(1.774)\end{array}$ & $\begin{array}{l}-0.0229^{* * *} \\
(3.391)\end{array}$ & $\begin{array}{l}-0.0240^{* * *} \\
(3.921)\end{array}$ \\
\hline Bilateral Debt (-1) & $\begin{array}{l}-0.0038 \\
(0.917)\end{array}$ & $\begin{array}{l}-0.0054 \\
(1.395)\end{array}$ & $\begin{array}{l}-0.0007 \\
(0.152)\end{array}$ & \\
\hline Private Debt (-1) & $\begin{array}{l}-0.0071 \\
(0.463)\end{array}$ & & $\begin{array}{l}-0.0054 \\
(0.622)\end{array}$ & $\begin{array}{l}0.0050^{* * *} \\
(2.994)\end{array}$ \\
\hline HIPC x Multilater. Debt (-1) & $\begin{array}{l}0.0049 \\
(0.344)\end{array}$ & & $\begin{array}{l}0.0190^{* * *} \\
(2.866)\end{array}$ & $\begin{array}{l}0.0196^{* * *} \\
(3.341)\end{array}$ \\
\hline HIPC x Bilateral Debt $(-1)$ & $\begin{array}{l}0.0156^{\star * *} \\
(2.650)\end{array}$ & $\begin{array}{l}0.0169^{* * *} \\
(3.070)\end{array}$ & $\begin{array}{l}-0.0007 \\
(0.147)\end{array}$ & \\
\hline HIPC $x$ Private Debt $(-1)$ & $\begin{array}{l}0.0042 \\
(0.250)\end{array}$ & & $\begin{array}{l}0.0112 \\
(1.200)\end{array}$ & \\
\hline Multilateral Net Loans (-1) & $\begin{array}{l}0.1051^{* * *} \\
(2.806)\end{array}$ & $\begin{array}{l}0.1033^{* * *} \\
(2.781)\end{array}$ & $\begin{array}{l}0.0113 \\
(0.744)\end{array}$ & \\
\hline Bilateral Net Loans (-1) & $\begin{array}{l}0.0381 \\
(1.108)\end{array}$ & & $\begin{array}{l}0.0013 \\
(0.110)\end{array}$ & \\
\hline Private Net Loans $(-1)$ & $\begin{array}{l}0.0354 \\
(1.097)\end{array}$ & & $\begin{array}{l}0.0118 \\
(0.941)\end{array}$ & \\
\hline Multilateral Grants (-1) & $\begin{array}{l}0.0196 \\
(0.824)\end{array}$ & & $\begin{array}{l}0.3088^{* * *} \\
(11.878)\end{array}$ & $\begin{array}{l}0.3188^{* * *} \\
(12.306)\end{array}$ \\
\hline HIPC $\times$ Multilateral Grants $(-1)$ & & & $\begin{array}{l}0.0690^{*} \\
(1.785)\end{array}$ & $\begin{array}{l}0.0559 \\
(1.522)\end{array}$ \\
\hline Bilateral Grants (-1) & $\begin{array}{l}0.5989 * * \star \\
(16.217)\end{array}$ & $\begin{array}{l}0.5969 * \star \star \\
(16.744)\end{array}$ & $\begin{array}{l}0.0720^{* * \star} \\
(5.733)\end{array}$ & $\begin{array}{l}0.0624^{\star * \star} \\
(6.276)\end{array}$ \\
\hline HIPC x Bilateral Grants $(-1)$ & $\begin{array}{l}0.0925^{\star * *} \\
(2.703)\end{array}$ & $\begin{array}{l}0.0986^{* * *} \\
(2.981)\end{array}$ & & \\
\hline Debt Forgiven (-1) & $\begin{array}{l}-1.3087^{* *} \\
(2.239)\end{array}$ & $\begin{array}{l}-1.3954^{* *} \\
(2.462)\end{array}$ & $\begin{array}{l}-0.1321 \\
(0.926)\end{array}$ & \\
\hline HIPC x Debt Forgiven $(-1)$ & $\begin{array}{l}0.7564 \\
(1.290)\end{array}$ & $\begin{array}{l}0.8564 \\
(1.506)\end{array}$ & $\begin{array}{l}0.1142 \\
(0.808)\end{array}$ & \\
\hline Dummy Post War & $\begin{array}{l}-0.0053^{*} \\
(1.679)\end{array}$ & $\begin{array}{l}-0.0054^{*} \\
(1.784)\end{array}$ & $\begin{array}{l}-0.0012 \\
(0.747)\end{array}$ & \\
\hline Constant & $\begin{array}{l}0.0104 \\
(1.300)\end{array}$ & $\begin{array}{l}0.0125^{* *} \\
(2.159)\end{array}$ & $\begin{array}{l}0.0005 \\
(0.127)\end{array}$ & $\begin{array}{l}0.0040^{*} \\
(1.888)\end{array}$ \\
\hline Observations & 936 & 936 & 936 & 936 \\
\hline Number of countries & 52 & 52 & 52 & 52 \\
\hline Number of years & 18 & 18 & 18 & 18 \\
\hline SE of regression & 0.0396 & 0.0395 & 0.0186 & 0.0185 \\
\hline SE of Dependent variable & 0.0797 & 0.07967 & 0.0430 & 0.0430 \\
\hline TD joint significance test & $\begin{array}{l}\text { Chi2 } 2(17)=70.27 \\
\text { Prob }>\text { chi2 }=0.000\end{array}$ & $\begin{array}{l}\text { Chi2(17) }=70.78 \\
\text { Prob }>\text { chi2 }=0.000\end{array}$ & $\begin{array}{l}\text { Chi2 } 2(17)=60.47 \\
\text { Prob }>\text { chi2 }=0.000\end{array}$ & $\begin{array}{l}\text { Chi2 }(17)=78.23 \\
\text { Prob }>\text { chi2 }=0.000\end{array}$ \\
\hline$C D$ joint significance test & $\begin{array}{l}\text { Chi2 }(51)=109.53 \\
\text { Prob }>\text { chi } 2=0.000\end{array}$ & $\begin{array}{l}\text { Chi } 2(51)=129.93 \\
\text { Prob }>\text { chi } 2=0.000\end{array}$ & $\begin{array}{l}\text { Chi } 2(51)=236.88 \\
\text { Prob }>\text { chi2 }=0.000\end{array}$ & $\begin{array}{l}\text { Chi } 2(51)=273.13 \\
\text { Prob }>\text { chi2 }=0.000\end{array}$ \\
\hline
\end{tabular}

Absolute value of t statistics in parentheses ${ }^{*}$ significant at $10 \%$; ${ }^{* *}$ significant at $5 \%$; ${ }^{* * *}$ significant at $1 \%$ Generalised least squares allowing for heteroskedastic errors. Each equation contains country dummies and time dummies. 
TABLE 8: Net Loans and Grants with interactions with HDEGC

\begin{tabular}{|c|c|c|c|c|}
\hline & Bilateral Net Loans & Mul Net Loans & Bilateral Grants & Mul Grants \\
\hline Population & $\begin{array}{l}0.0244^{*} \\
(1.937)\end{array}$ & $\begin{array}{l}-0.0309^{* \star} \\
(2.047)\end{array}$ & $\begin{array}{l}-0.0265 \\
(0.964)\end{array}$ & $\begin{array}{l}-0.0073 \\
(0.475)\end{array}$ \\
\hline Pc-GDP (-1) & $\begin{array}{l}-0.0017 \\
(0.636)\end{array}$ & $\begin{array}{l}-0.0019 \\
(0.634)\end{array}$ & $\begin{array}{l}-0.0059 \\
(1.533)\end{array}$ & $\begin{array}{l}-0.0025 \\
(1.330)\end{array}$ \\
\hline Inflation (-1) & $\begin{array}{l}0.0001 \\
(1.157)\end{array}$ & $\begin{array}{l}0.00002 \\
(0.632)\end{array}$ & $\begin{array}{l}0.00002 \\
(0.426)\end{array}$ & $\begin{array}{l}0.00001 \\
(0.633)\end{array}$ \\
\hline Gr-GDP $(-1)$ & $\begin{array}{l}-0.0216^{\star * \star} \\
(2.758)\end{array}$ & $\begin{array}{l}0.0175^{\star *} \\
(2.123)\end{array}$ & $\begin{array}{l}0.0163 \\
(1.185)\end{array}$ & $\begin{array}{l}-0.0250^{\star * *} \\
(4.121)\end{array}$ \\
\hline Openness $(-1)$ & $\begin{array}{l}0.0058^{* *} \\
(1.965)\end{array}$ & $\begin{array}{l}-0.0008 \\
(0.426)\end{array}$ & $\begin{array}{l}-0.0015 \\
(0.512)\end{array}$ & $\begin{array}{l}-0.0001 \\
(0.042)\end{array}$ \\
\hline PRCL & $\begin{array}{l}-0.0004 \\
(1.136)\end{array}$ & $\begin{array}{l}0.0003 \\
(0.940)\end{array}$ & $\begin{array}{l}0.0011^{*} \\
(1.934)\end{array}$ & $\begin{array}{l}-0.0002 \\
(1.010)\end{array}$ \\
\hline Multilateral Debt Share $(-1)$ & $\begin{array}{l}0.0016 \\
(0.204)\end{array}$ & $\begin{array}{l}-0.0490^{\star \star *} \\
(4.818)\end{array}$ & $\begin{array}{l}-0.0241 \\
(1.458)\end{array}$ & $\begin{array}{l}-0.0147^{*} \\
(1.944)\end{array}$ \\
\hline Bilateral Debt Share $(-1)$ & $\begin{array}{l}-0.0189 \\
(1.636)\end{array}$ & $\begin{array}{l}0.0231^{*} \\
(1.884)\end{array}$ & $\begin{array}{l}0.0230 \\
(1.122)\end{array}$ & $\begin{array}{l}0.0131 \\
(1.311)\end{array}$ \\
\hline Private Debt Share $(-1)$ & $\begin{array}{l}-0.0141 \\
(1.000)\end{array}$ & $\begin{array}{l}0.0356^{* * *} \\
(3.057)\end{array}$ & $\begin{array}{l}0.0046 \\
(0.251)\end{array}$ & $\begin{array}{l}0.0062 \\
(0.709)\end{array}$ \\
\hline HDEG $\times$ Mul Debt Share $(-1)$ & $\begin{array}{l}-0.0053 \\
(0.771)\end{array}$ & $\begin{array}{l}0.0220^{* *} \\
(2.484)\end{array}$ & $\begin{array}{l}0.0167 \\
(1.128)\end{array}$ & $\begin{array}{l}0.0091 \\
(1.326)\end{array}$ \\
\hline HDEG x Bilateral Debt Share $(-1)$ & $\begin{array}{l}0.0064 \\
(0.565)\end{array}$ & $\begin{array}{l}-0.0215^{*} \\
(1.771)\end{array}$ & $\begin{array}{l}-0.0167 \\
(0.821)\end{array}$ & $\begin{array}{l}-0.0137 \\
(1.383)\end{array}$ \\
\hline HDEG $\times$ Private Debt Share $(-1)$ & $\begin{array}{l}0.0126 \\
(0.950)\end{array}$ & $\begin{array}{l}-0.0335^{\star \star \star} \\
(3.022)\end{array}$ & $\begin{array}{l}-0.0068 \\
(0.394)\end{array}$ & $\begin{array}{l}-0.0034 \\
(0.406)\end{array}$ \\
\hline Multilateral Net Loans $(-1)$ & $\begin{array}{l}0.0252 \\
(1.190)\end{array}$ & $\begin{array}{l}0.4931^{* * *} \\
(16.475)\end{array}$ & $\begin{array}{l}0.1065^{\star * *} \\
(2.774)\end{array}$ & $\begin{array}{l}0.0031 \\
(0.204)\end{array}$ \\
\hline Bilateral Net Loans $(-1)$ & $\begin{array}{l}0.4946^{* * *} \\
(16.330)\end{array}$ & $\begin{array}{l}0.0019 \\
(0.088)\end{array}$ & $\begin{array}{l}0.0329 \\
(0.959)\end{array}$ & $\begin{array}{l}-0.0042 \\
(0.384)\end{array}$ \\
\hline Private Net Loans $(-1)$ & $\begin{array}{l}0.0296 \\
(1.194)\end{array}$ & $\begin{array}{l}0.0190 \\
(0.881)\end{array}$ & $\begin{array}{l}0.0354 \\
(1.098)\end{array}$ & $\begin{array}{l}0.0144 \\
(1.131)\end{array}$ \\
\hline $\begin{array}{l}\text { Multilateral Grants }(-1) \\
\text { HDEG x Multilateral Grants }(-1)\end{array}$ & $\begin{array}{l}-0.0063 \\
(0.354)\end{array}$ & $\begin{array}{l}-0.0024 \\
(0.179)\end{array}$ & $\begin{array}{l}0.0502 \\
(1.600)\end{array}$ & $\begin{array}{l}0.2550^{* * *} \\
(9.841) \\
0.1863^{* * *} \\
(4.773)\end{array}$ \\
\hline Bilateral Grants (-1) & -0.0124 & $0.0899^{* * *}$ & $\begin{array}{l}0.6542^{* * *} \\
(13.250)\end{array}$ & $\begin{array}{l}0.0625^{\star * *} \\
(4.988)\end{array}$ \\
\hline Bilateral HDEG Grants (-1) & & & $\begin{array}{l}-0.0009 \\
(0.019)\end{array}$ & \\
\hline Debt Forgiven (-1) & & & $\begin{array}{l}-1.0866 \\
(1.096)\end{array}$ & $\begin{array}{l}0.0682 \\
(0.173)\end{array}$ \\
\hline HDEG x Debt Forgiven (-1) & $(0.890)$ & $(6.392)$ & $\begin{array}{l}0.5100 \\
(0.514)\end{array}$ & $\begin{array}{l}-0.0731 \\
(0.186)\end{array}$ \\
\hline Dummy Post War & $\begin{array}{l}-0.0000 \\
(0.027)\end{array}$ & $\begin{array}{l}-0.0016 \\
(0.798)\end{array}$ & $\begin{array}{l}-0.0042 \\
(1.244)\end{array}$ & $\begin{array}{l}-0.0007 \\
(0.427)\end{array}$ \\
\hline Constant & $\begin{array}{l}0.0023 \\
(0.395) \\
\end{array}$ & $\begin{array}{l}0.0001 \\
(0.014)\end{array}$ & $\begin{array}{l}0.0103 \\
(1.292) \\
\end{array}$ & $\begin{array}{l}0.0022 \\
(0.569) \\
\end{array}$ \\
\hline $\begin{array}{l}\text { Observations } \\
\text { Number of countries } \\
\text { Number of years } \\
\text { SE of regression } \\
\text { SE of Dependent variable } \\
\text { TD joint significance test } \\
\text { CD joint significance test }\end{array}$ & $\begin{array}{l}936 \\
52 \\
18 \\
0.0257 \\
0.0386 \\
\text { chi2 }(17)=36.45 \\
\text { Prob }>\text { chi2 }=0.004 \\
\text { chi2 }(51)=64.81 \\
\text { Prob }>\text { chi2 } 2=0.092\end{array}$ & $\begin{array}{l}936 \\
52 \\
18 \\
0.0259 \\
0.0388 \\
\text { chi2 }(17)=29.04 \\
\text { Prob }>\text { chi2 }=0.034 \\
\text { chi2 }(51)=128.76 \\
\text { Prob }>\text { chi } 2=0.000\end{array}$ & $\begin{array}{l}936 \\
52 \\
18 \\
0.0401 \\
0.0797 \\
\text { chi2 }(17)=67.25 \\
\text { Prob }>\text { chi2 }=0.000 \\
\text { chi2 }(51)=122.64 \\
\text { Prob }>\text { chi } 2=0.000\end{array}$ & $\begin{array}{l}936 \\
52 \\
18 \\
0.0184 \\
0.0430 \\
\text { chi2 }(17)=55.52 \\
\text { Prob }>\text { chi } 2=0.000 \\
\text { chi2 }(51)=236.61 \\
\text { Prob }>\text { chi } 2=0.000\end{array}$ \\
\hline
\end{tabular}




\section{FIGURE 1}

\section{TOTAL EXTERNAL DEBT \% GDP}

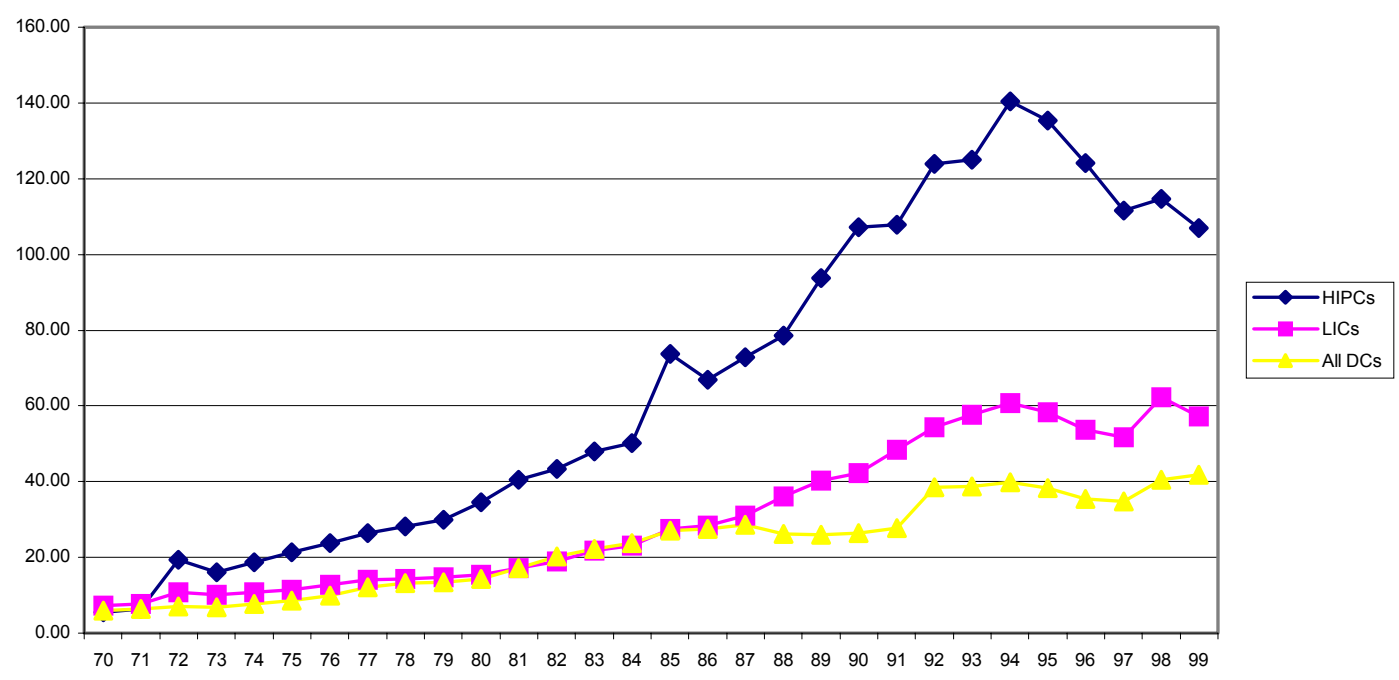

FIGURE 2

TOTAL NET LOANS and TOTAL DEBT SERVICE \% GDP - HIPCS

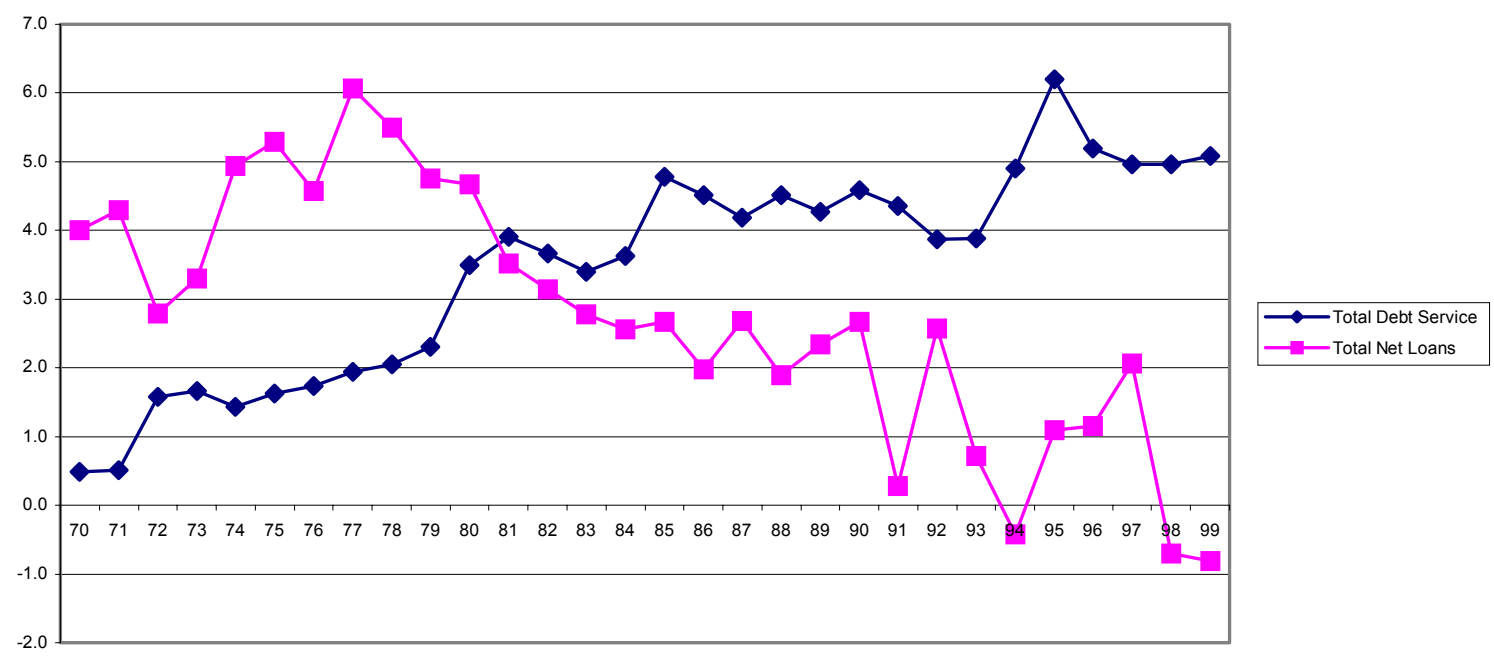




\section{FIGURE 3}

TOTAL NET LOANS AND GRANTS \% GDP - HIPC

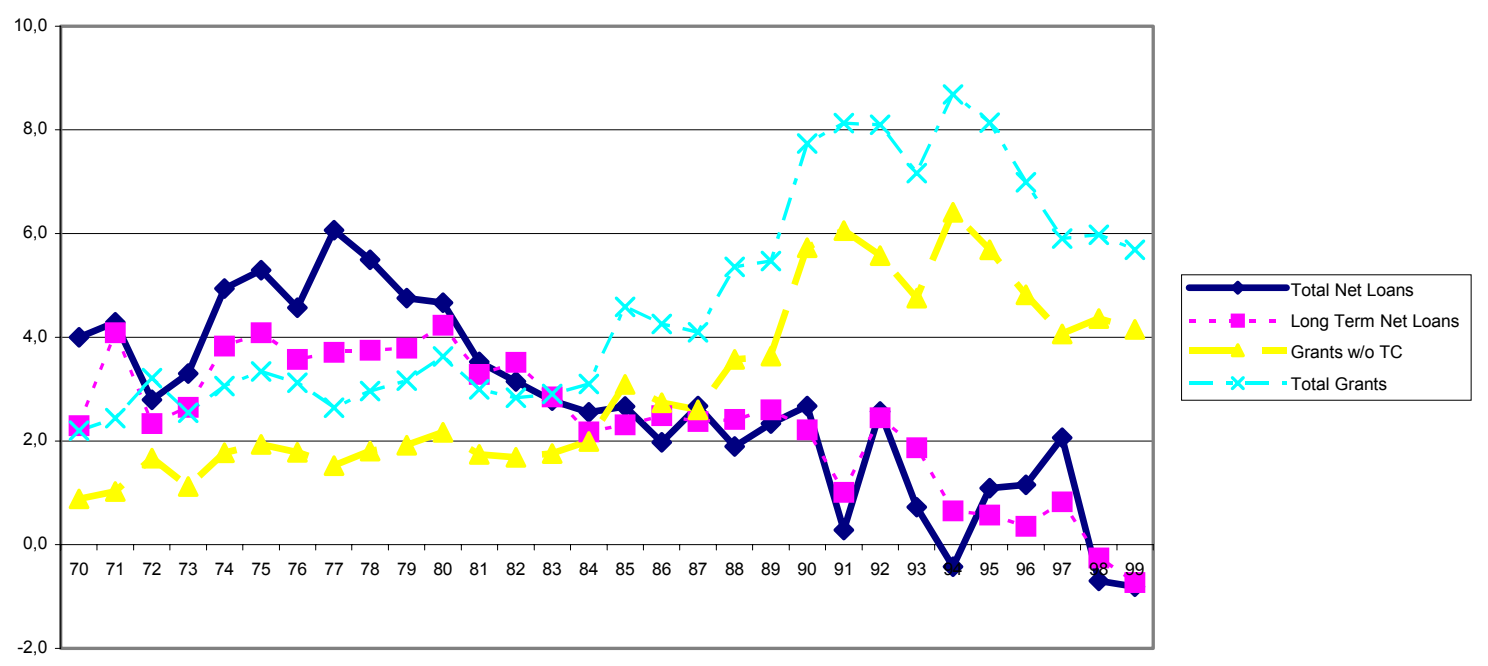

FIGURE 4

TOTAL NET LOANS and TOTAL NET LOANS \& GRANTS \% GDP - HIPCs

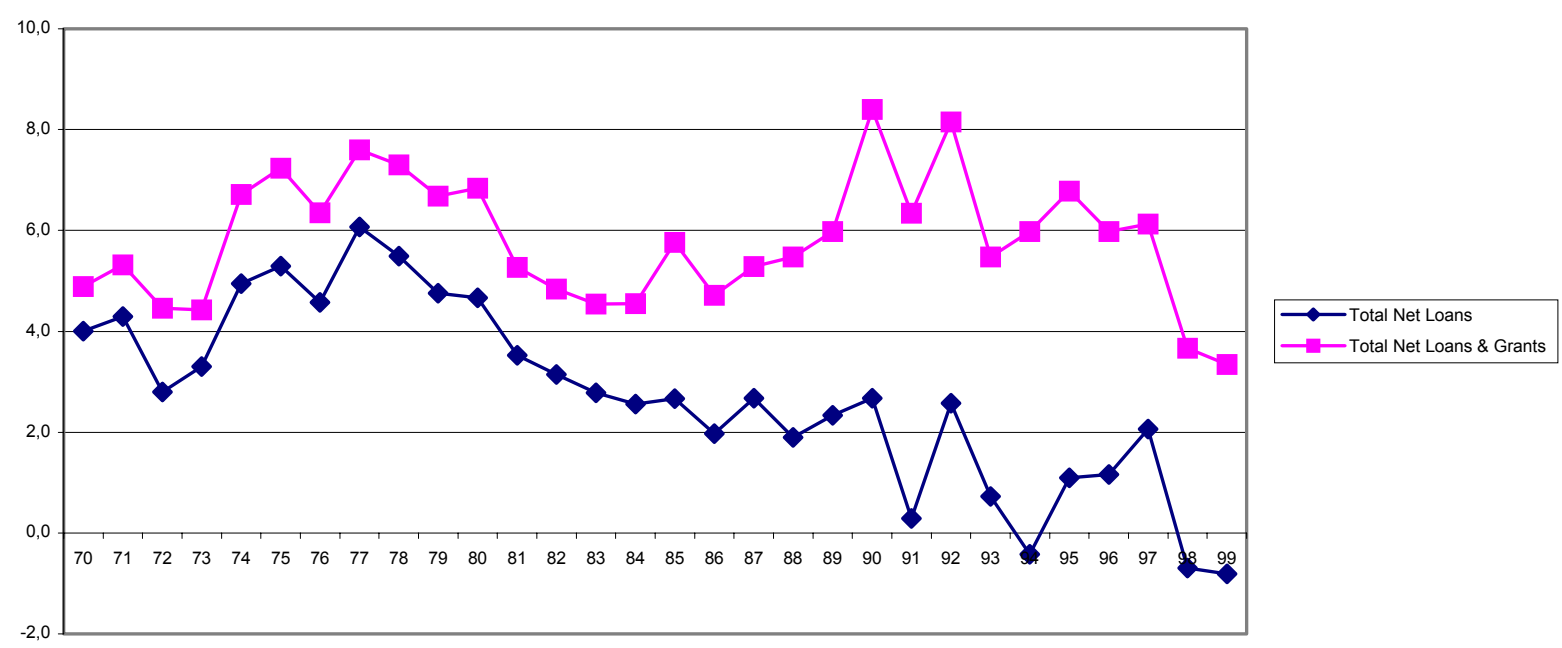




\section{FIGURE 5}

LONG TERM DEBT by TYPE of CREDITOR \% LONG TERM DEBT - HIPCs

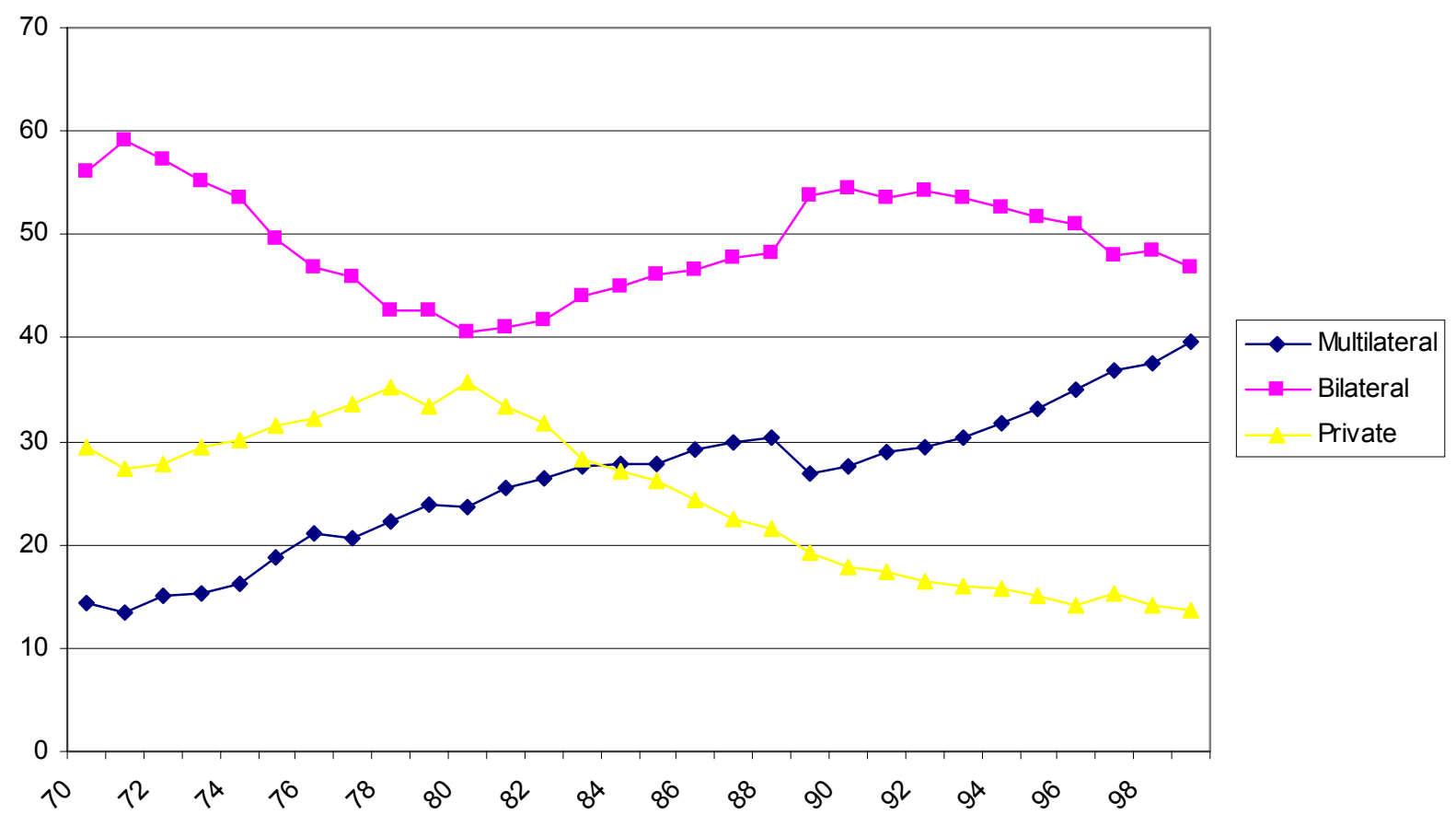

\section{FIGURE 6}

TOTAL GRANTS by DONORS \% GDP - HIPCs

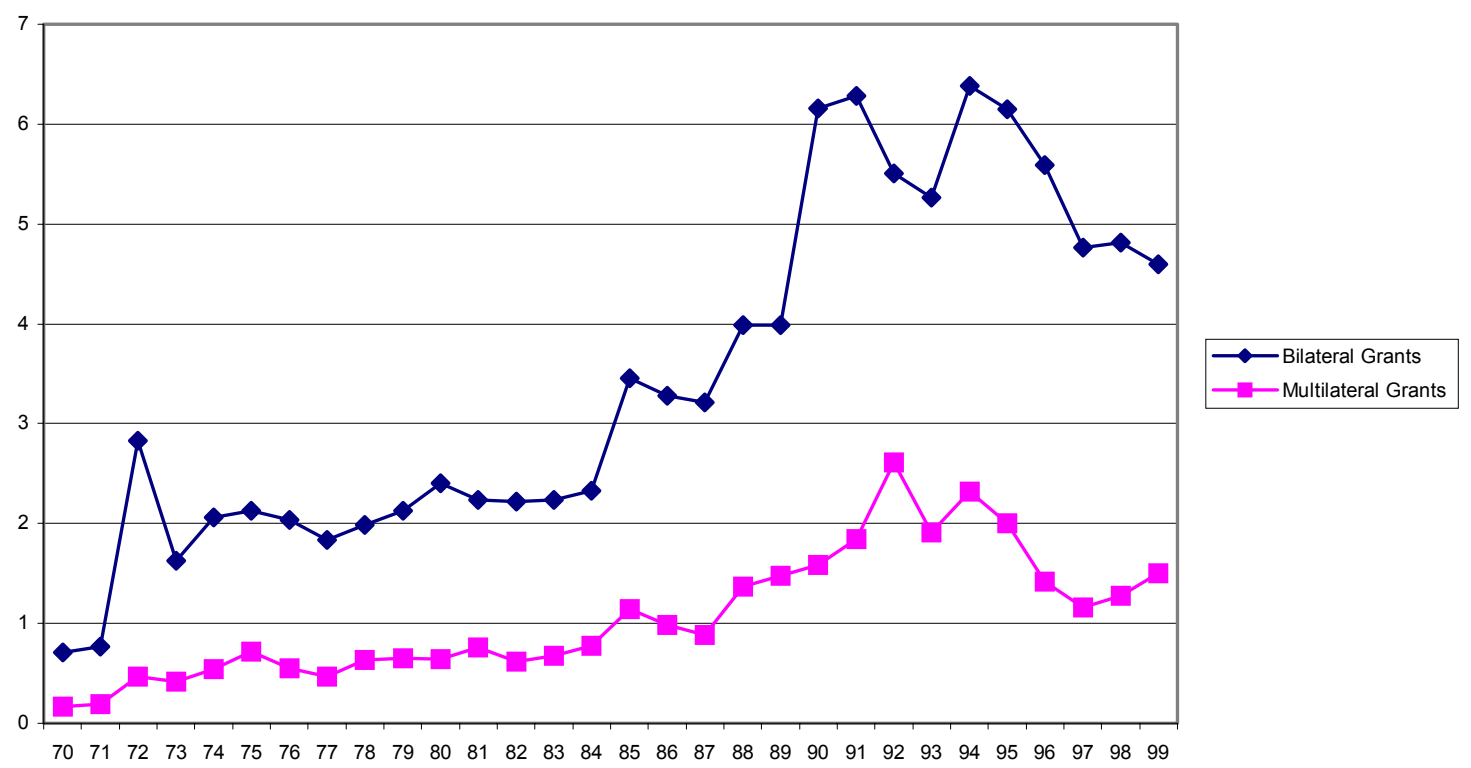


FIGURE 7

COMPOSITION OF LONG TERM DEBT by TYPE PF CREDITOR - HIPCs

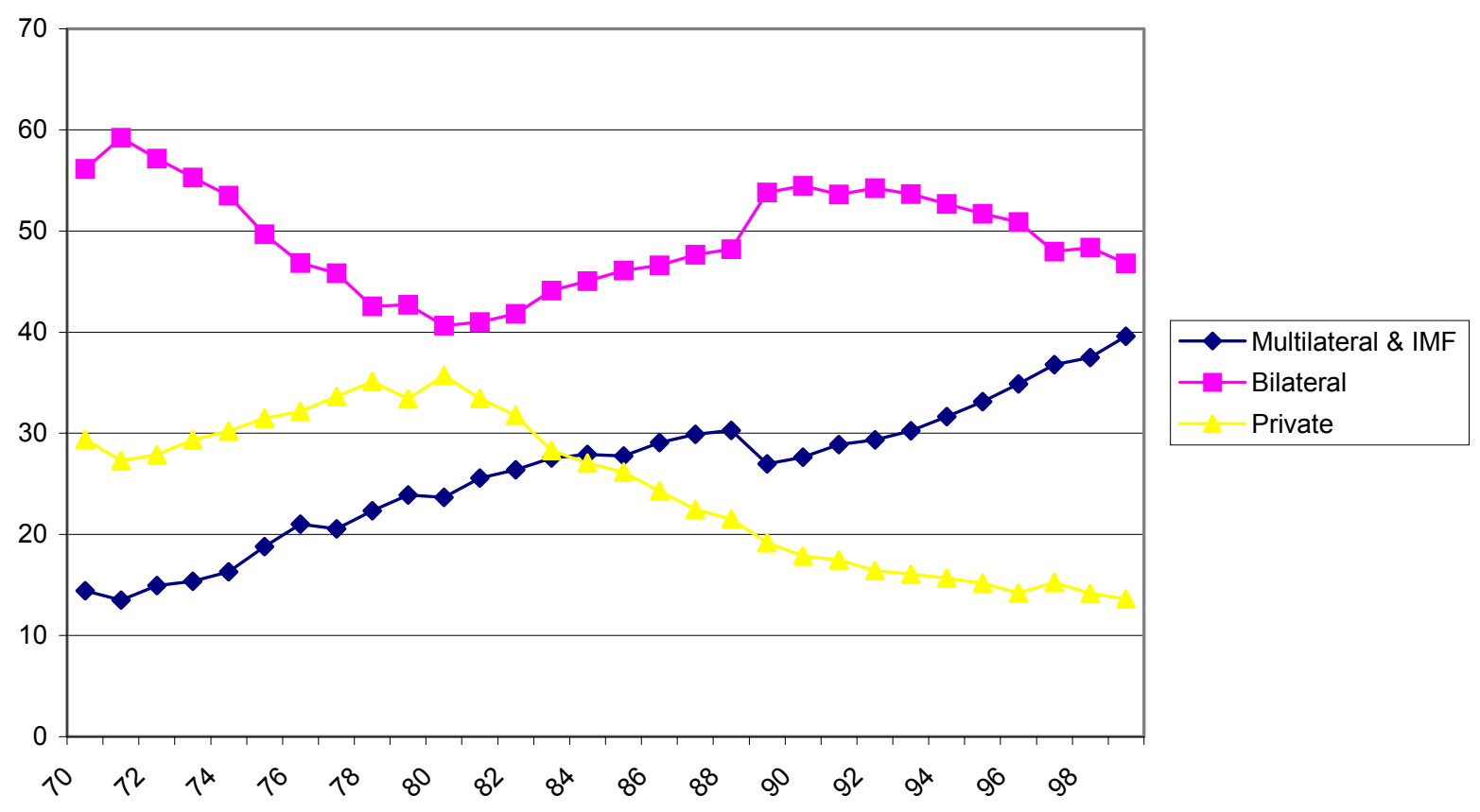

